\title{
Dissecting the Dynamics of the US Trade Balance in an Estimated Equilibrium Model*
}

\author{
Punnoose Jacob \\ Gert Peersman \\ Ghent University \\ Ghent University
}

This version: February 2011

First version: November 2008

\begin{abstract}
In an estimated two-country DSGE model, we find that efficiency shocks specific to investment account for more than half of the forecast variance of cyclical fluctuations in the US trade balance. Both domestic and foreign investment-specific shocks have a substantial impact on the variability of the imbalance. Total factor productivity shocks do not matter for the variance and even lead to procyclicality in the trade balance.
\end{abstract}

JEL classification: C11, F41

Keywords: Open Economy Macroeconomics, US Trade Balance, Investment Shocks, Bayesian Estimation of DSGE Models.

\footnotetext{
${ }^{*}$ We acknowledge financial support from the Inter-University Attraction Poles Program-Belgium Science Policy (Contract Number P6/07) and the Flemish Fund for Scientific Research (FWO). This paper was in part written while the first author was visiting the National Bank of Belgium under the Internship Programme for young researchers. A special thanks to Raf Wouters for constant advice. We also thank two anonymous referees, Lieven Baert, Christiane Baumeister, Mathieu Bussiére, Julio Carrillo, Lilia Cavallari, Fabrice Collard, Giancarlo Corsetti, Ferre de Graeve, David de La Croix, Gregory de Walque, Rafael Domenéch, Nicolas Groshenny, Freddy Heylen, Chiara Forlati, Francesco Furlanetto, Mathias Hoffmann, Robert Kollmann, Luisa Lambertini, Vivien Lewis, Giulio Nicoletti, Pau Rabanal, Morten Ravn, Frank Smets, Arnoud Stevens, Lenno Uusküla, Ine Van Robays, participants at the Dynare Conference 2008, ICMAIF 2009, Congress of the European Economic Association 2009, Reserve Bank of New Zealand Conference on the Transmission of International Shocks to Open Economies 2010 and seminar participants at the National Bank of Belgium for helpful suggestions. All remaining errors are ours. The views expressed herein do not necessarily reflect those of the National Bank of Belgium.
} 


\section{Introduction}

A vast literature in international macroeconomics has focused on the deterioration of the external position of the United States (US) and its consequences for the global economy. ${ }^{1}$ This paper disentangles the stochastic influences on the US trade balance over the last three decades by estimating a two-country dynamic stochastic general equilibrium (DSGE) model with fourteen structural innovations using Bayesian methods. The model can be seen as a two-country version of the closed-economy models described in Smets and Wouters $(2003,2007)$, where the second 'country' is a trade-weighted aggregate of sixteen OECD partners with whom the US has experienced deficits for a reasonably long span of time.

Several authors, examining different facets of the US external position using diverse methodologies, have identified a causal link between movements in the efficiency of US factors of production and the external balance. Bussière, Fratzscher and Müller (2005) find empirical support for shifts in total factor productivity (TFP) having a significantly negative impact on the US current account. Corsetti, Dedola and Leduc (2006) report a negative association between productivity shocks in US manufacturing and US netexports while Corsetti and Konstantinou (2009) find that permanent technological shocks raise US consumption and net foreign liabilities persistently. Also in the theoretical literature, Backus, Kydland and Kehoe (1994) and Kollmann (1998) explain trade balance fluctuations on the basis of TFP shocks in calibrated two-country DSGE models.

This paper endorses the 'efficiency' view prevalent in the literature, but with some important qualifications. More specifically, efficiency shocks matter for the US trade balance only if they are specific to investment. Across a spectrum of model specifications, we find compelling evidence that investment efficiency shocks explain more than half of the forecast variance of US net-exports over the cycle. Both domestic investment shocks and those emanating from the rest of the world (RoW) have a substantial impact on the variance of the imbalance. On the other hand, neutral technological shocks, as in TFP, have little impact on the variance. The US TFP shock even improves the trade balance in impulse responses as the decline of US prices generates a positive effect on US exports due

\footnotetext{
${ }^{1}$ In 2010 Q3, the US trade deficit touched the 537 billion dollar mark on an annualized basis and as a proportion of GDP equalled 3.64 percent (FRED II data). In this paper, we restrict the attention to the cycle of the trade balance while abstracting from the trend. Other authors, e.g. Engel and Rogers (2006) have examined the long-run path of the US trade balance.
} 
to a deterioration of the terms of trade. We also observe a relevant impact of uncovered interest parity (UIP) innovations on trade balance fluctuations, but the magnitude is lower than in other studies (e.g. Bergin 2006). Furthermore, we find a limited role for domestic and foreign wage mark-up, consumption time-impatience, monetary and fiscal policy shocks, as well as purchasing power parity disturbances.

This paper lies at the interface of several strands of the literature. First, our results that underscore the importance of investment efficiency shocks for the US trade balance complement the findings of closed-economy studies that emphasize the relevance of these shocks for the overall US business cycle. For instance, Justiniano, Primiceri and Tambalotti $(2010,2011)$, henceforth JPT $(2010,2011)$, find that investment efficiency shocks are the most important drivers of US business cycle fluctuations in the post-war period. In fact, we even find a significant greater importance of domestic and foreign investment shocks for the external position of the US than for domestic GDP. This is not a surprise given that we allow for different shares of imports in consumption and investment goods in the estimations and the fact that about three quarters of US non-fuel imports and exports are capital goods and consumer durables, which contrasts with an investment share in domestic GDP of about 20 percent, as documented by Erceg, Guerrieri and Gust (2008). When we employ the traditional specification seen in e.g. Backus, Kydland and Kehoe (1994), that allows imports to be dependent only on aggregate absorption, the reaction of the trade balance to investment shocks is more subdued.

The paper is also related to a number of macroeconometric studies that assess the driving forces of the US trade balance. Bems, Dedola and Smets (2007) find that fiscal shocks and investment-specific technological change have had a negative influence on the trade balance, but they focus solely on the influence of domestic shocks in a structural vector autoregression framework. Bergin (2006) uses maximum likelihood techniques to estimate a small-scale New Keynesian model of the US and the remaining of the G-7 countries and finds that UIP and taste shocks explain the bulk of trade balance fluctuations, especially in the short-run. We find a more suppressed role for these shocks as we employ other frictions, observable data series and shocks, in particular investment and corresponding disturbances. ${ }^{2}$

Finally, we contribute to the recent tradition of New Keynesian two-country mod-

\footnotetext{
${ }^{2}$ Importantly, Bergin (2006) also estimates the model in country-differences and hence can only identify relative shocks. Our model is asymmetric as we allow parameters and shocks to vary across countries.
} 
els estimated with Bayesian methods seen in Rabanal and Tuesta (2010) and Lubik and Schorfheide (2006). These authors study the dynamics of the Euro-Dollar exchange rate while we focus on the trade balance. Our model is also much less stylized and the considerably richer data-set that we employ in its empirical implementation enables the identification of a wider array of structural shocks.

We proceed as follows. The next section details the baseline theoretical model we set up. Section 3 presents the estimation results from this model. In Section 4, we carefully evaluate the robustness of the main findings by subjecting the baseline model to perturbations and examine the sources of differences relative to the existing literature. Finally, Section 5 concludes.

\section{A Benchmark Two-Country Model}

The baseline specification we use can be seen as a two-country version of the closedeconomy models described in Smets and Wouters (2003, 2007), henceforth SW (2003, 2007). The open-economy dimension deviates from the convention in only one aspect, i.e. the treatment of the intensity of imports in aggregate consumption and investment. ${ }^{3}$ Erceg et al. (2008) note that in the data, US exports and imports are heavily concentrated towards capital goods and durables, making the consumption basket considerably less open to imports than the investment basket. Hence, following these authors, we allow for different shares of imports in each. ${ }^{4}$ Since the two countries in the model are isomorphic, we only present equilibrium conditions for the Home economy that are log-linearized around a simple symmetric non-stochastic steady-state with balanced trade and no inflation or exchange rate depreciation. Variables presented as logarithmic deviations from the steadystate are denoted by a superscript ${ }^{`}$, , while $\Delta$ indicates the temporal difference operator. Typically, foreign-country variables and parameters are denoted with a superscript ' * '.

\footnotetext{
${ }^{3}$ In line with the empirical New Keynesian literature, e.g. Rabanal and Tuesta (2010), Bergin (2006), Lubik and Schorfheide (2006) and De Walque, Smets and Wouters (2005), we impose the same values for the steady-state shares and open-economy parameters across the two countries. To preserve empirical tractability, just as our precedents, we do not model a non-tradable sector.

${ }^{4}$ Erceg et al. (2008) compare this 'disaggregated' specification with the popular 'aggregated' Armington specification, which assumes the existence of a final good sector that combines domestic and imported goods to produce a composite good that is used for both consumption and investment, disallowing the use of different import-intensities. Backus et al. (1994), De Walque, Smets and Wouters (2005), Bergin (2006) and Raffo (2008) use the aggregated specification.
} 
The innovations in all the $\mathrm{AR}(1)$ processes, $\eta^{x}$ are i.i.d. $\mathcal{N}\left(0, \sigma_{x}\right)$ and $\rho_{x} \in[0,1) \forall x$. We follow Bergin (2006) in abstracting from balanced growth and as in SW (2007), all the shocks in the theoretical model are normalized so that they enter the estimation with a unit coefficient. In Section 4, we discuss the robustness of the results when alternative specifications for our benchmark model are used.

Final Goods Sector As in Erceg et al. (2008), an aggregation sector produces Armington aggregates of the composite Home and imported bundles for final consumption $(C)$ and final investment $(I) . Z \in\{C, I\}$ denotes the output of the final goods sector for either consumption or investment. In the Armington aggregator, $Z$ is a combination of the domestic bundle $Z_{H}$ and the imported bundle $Z_{F}$ that are in turn Dixit-Stiglitz aggregates of differentiated intermediate varieties. The analogs in the foreign country are indicated by $Z_{F}^{*}$ and $Z_{H}^{*}$. $\xi_{Z} \in(0,1)$ denotes the share of imports in the respective aggregator for consumption and investment. The price index of the domestic bundle (GDP deflator) is denoted by $P_{H}$ in the home region and $P_{F}^{*}$ in the foreign region. Imports at home are sold at a price $P_{F}$ while the analogous price in the Foreign region is given by $P_{H}^{*}$. The aggregate price levels, i.e. the consumer price index and the investment deflator, are convex combinations of the GDP deflator and the price of imports.

$$
\hat{P}_{Z t}=\left(1-\xi_{Z}\right) \hat{P}_{H t}+\xi_{Z} \hat{P}_{F t}
$$

We define $\widehat{T o T} \equiv \hat{P}_{F}-\hat{P}_{H}$ and $\widehat{T o T}^{*} \equiv \hat{P}_{H}^{*}-\hat{P}_{F}^{*}$ as the Home and Foreign terms of trade that determine the rate at which agents substitute the imported bundle for the domestically produced bundle. If $\mu>0$ denotes the trade-elasticity, the demand functions for the domestic bundle and imported bundle are given as

$$
\begin{gathered}
\hat{Z}_{H t}=\hat{Z}_{t}+\mu \xi_{Z} \widehat{T o T}_{t} \\
\hat{Z}_{F t}-\hat{Z}_{H t}=-\mu \widehat{T o T}_{t}
\end{gathered}
$$

Intermediate Sector There exists a continuum of intermediate monopolistic firms, each of which produces a differentiated variety. The firm rents capital services $K^{S}$ and labor $N$ at (GDP deflator-based) real rates $r^{k}$ and $w$ and combines the factors in a Cobb-Douglas aggregate.

$$
\hat{Y}_{H t}=\frac{\chi_{P}}{\chi_{P}-1}\left[(1-\alpha) \hat{N}_{t}+\alpha \hat{K}_{t}^{S}+\varepsilon_{t}^{T F P}\right]
$$


$\alpha$ is the share of capital services in the production function and exogenous TFP follows $\varepsilon_{t}^{T F P}=\rho_{T F P} \varepsilon_{t-1}^{T F P}+\eta_{t}^{T F P} \cdot \chi_{P}>1$ is the elasticity of substitution between individual goods varieties which determines the long-run mark-up of prices over marginal costs. The return on capital is determined by

$$
\hat{r}_{t}^{k}+\hat{K}_{t}^{S}=\hat{w}_{t}+\hat{N}_{t}
$$

As seen in Rabanal and Tuesta (2010), the firm sets prices in the local currency in the market of destination and exchange rate pass-through is decreasing in the degree of price stickiness. $\theta_{H} \in(0,1)$ and $\theta_{H}^{*} \in(0,1)$ are the Calvo probability parameters for domestic sales and exports respectively, while $\iota_{P} \in[0,1]$ denotes the degree of price indexation for domestic sales. If $\beta \in(0,1)$ is the agent's subjective discount factor and $\mathbf{E}_{t}$ is the expectation operator conditional on the information set at the beginning of period $t$, the Phillips curve for domestic sales is given by

$$
\hat{\pi}_{H t}=\frac{\iota_{P}}{1+\beta \iota_{P}} \hat{\pi}_{H t-1}+\frac{\beta}{1+\beta \iota_{P}} \mathbf{E}_{t} \hat{\pi}_{H t+1}+\frac{\left(1-\beta \theta_{H}\right)\left(1-\theta_{H}\right)}{\theta_{H}\left(1+\beta \iota_{P}\right)}\left[(1-\alpha) \hat{w}_{t}+\alpha \hat{r}_{t}^{k}-\varepsilon_{t}^{T F P}\right]
$$

As we do not fit export-import price series in the baseline estimation, we keep the exportpricing equations simple by abstracting from indexation. The assumption of local currency pricing implies that the real exchange rates $R E R^{Z}$ and the terms of trade enter the Phillips curves for export sales. ${ }^{5}$

$$
\hat{\pi}_{H t}^{*}=\beta \mathbf{E}_{t} \hat{\pi}_{H t+1}^{*}+\frac{\left(1-\beta \theta_{H}^{*}\right)\left(1-\theta_{H}^{*}\right)}{\theta_{H}^{*}}\left[\begin{array}{c}
(1-\alpha) \hat{w}_{t}+\alpha \hat{r}_{t}^{k}-\varepsilon_{t}^{T F P} \\
-\widehat{R E R}_{t}^{Z}-\xi_{Z} \widehat{T o T}_{t}-\left(1-\xi_{Z}\right) \widehat{T o T}_{t}^{*}
\end{array}\right]
$$

Real Exchange Rate A rise in the nominal exchange rate denoted by $N E R$ implies a depreciation of the Home currency. We use the real depreciation of the US dollar as an observed variable in our estimations and follow Lubik and Schorfheide (2006) in allowing for an i.i.d. disturbance $\eta^{P P P}$ to enter the definition of the real exchange rate. This shock captures deviations from purchasing power parity not accounted for by endogenous frictions such as local currency pricing and home-bias in trade and hence will help the model fit the exchange rate series better.

$$
\Delta \widehat{R E R}_{t}^{Z}=\Delta \widehat{N E R}_{t}+\hat{\pi}_{Z t}^{*}-\hat{\pi}_{Z t}+\eta_{t}^{P P P}
$$

\footnotetext{
${ }^{5}$ The indexation of the real exchange rate and the share of imports by $Z$, implies that the nominal exchange rate can be expressed in terms of the CPI-based as well as the investment deflator-based real exchange rates.
} 
Consumption and Investment Consumers have access to domestic and foreign currency denominated private risk-free bonds as well as the domestic capital stock to facilitate the inter-temporal transfer of wealth. Optimization yields three asset-pricing conditions.

$$
\begin{gathered}
\hat{C}_{t}=\frac{1}{1+\vartheta} \mathbf{E}_{t} \hat{C}_{t+1}+\frac{\vartheta}{1+\vartheta} \hat{C}_{t-1}-\frac{1}{\sigma_{C}} \frac{(1-\vartheta)}{(1+\vartheta)}\left(\hat{R}_{t}-\mathbf{E}_{t} \hat{\pi}_{C t+1}\right)+\varepsilon_{t}^{T I} \\
\mathbf{E}_{t} \widehat{N E R}_{t+1}-\widehat{N E R}_{t}=\hat{R}_{t}-\left(\hat{R}_{t}^{*}-\kappa \widehat{N F A}_{t}+\varepsilon_{t}^{U I P}\right) \\
\widehat{T Q}_{t}=(1-\beta(1-\delta)) \mathbf{E}_{t} \hat{r}_{t+1}^{k}+\beta(1-\delta) \mathbf{E}_{t} \widehat{T Q}_{t+1}-\left(\hat{R}_{t}-\mathbf{E}_{t} \hat{\pi}_{C t+1}\right)
\end{gathered}
$$

Equation 9 determines the flow of aggregate consumption. The curvature parameter $\sigma_{C}>0$ and the external habit coefficient $\vartheta \in[0,1)$ govern the inter-temporal elasticity of substitution. $R$ is the gross interest rate on domestic bonds set by the monetary authority while $\pi_{C}$ is the gross inflation in the consumer price index. $\varepsilon^{T I}$ is a disturbance that can be interpreted as a 'time-impatience' shock to the subjective discount factor and evolves as $\varepsilon_{t}^{T I}=\rho_{T I} \varepsilon_{t-1}^{T I}+\eta_{t}^{T I}$. Equation 10 presents uncovered interest parity (UIP), the arbitrage condition for home and foreign bonds. Since the failure of UIP in its primitive form has been well documented, we add to this condition a stochastic term $\varepsilon^{U I P}$ whose evolution obeys $\varepsilon_{t}^{U I P}=\rho_{U I P} \varepsilon_{t-1}^{U I P}+\eta_{t}^{U I P}$. The additional cost of acquiring net foreign assets NFA measured by $\kappa>0$ acts as a stationarity-inducing device. ${ }^{6}$ The third asset-pricing condition in Equation 11 determines the behavior of Tobin's Q.

Two key relationships that influence the dynamics of aggregate investment and the physical capital stock $(\bar{K})$ are

$$
\begin{gathered}
\hat{I}_{t}=\frac{\beta}{1+\beta} \mathbf{E}_{t} \hat{I}_{t+1}+\frac{1}{1+\beta} \hat{I}_{t-1}+\frac{1}{\psi(1+\beta)}\left(\widehat{T Q}_{t}-\xi_{I} \widehat{T o T}_{t}\right)+\varepsilon_{t}^{I N V} \\
\widehat{\bar{K}}_{t}=\delta \hat{I}_{t}+(1-\delta) \widehat{\bar{K}}_{t-1}+\delta \psi(1+\beta) \varepsilon_{t}^{I N V}
\end{gathered}
$$

$\delta \in(0,1)$ denotes the depreciation rate of the capital stock. Aggregate investment rises if Tobin's $\mathrm{Q}(\widehat{T Q})$ exceeds the relative price of investment in terms of output which is given

\footnotetext{
${ }^{6}$ See Bergin (2006) and the references therein for details of the non-stationarity problem in incomplete market models.
} 
by $\xi_{I} \widehat{T o T} .{ }^{7}$ The adjustment cost parameter $\psi>0$ increases the inertia in the response of investment. $\varepsilon^{I N V}$ is a stochastic shifter that increases the efficiency of the conversion of a unit of saving into the physical capital stock and evolves as $\varepsilon_{t}^{I N V}=\rho_{I N V} \varepsilon_{t-1}^{I N V}+\eta_{t}^{I N V}$. JPT (2011) show that these disturbances could stem from efficiency shocks to the process by which finished investment goods are turned into productive capital, as well as from technological factors specific to the production of investment goods as in Greenwood, Hercowitz and Krussel (1997). In the baseline model, we ignore the underlying structural origin of the efficiency and, as in SW $(2003,2007)$ and JPT (2010), refer to $\varepsilon^{I N V}$ simply as an investment shock. In Section 4, we will discuss the results of a model that further distinguishes between the stochastic sources of investment efficiency.

The capital services that enter the firm's production function depend on the lagged physical capital stock and the degree of capacity utilization that is a function of the rental rate of capital. $\varphi \in[0,1]$ governs the strength of capacity utilization.

$$
\hat{K}_{t}^{S}=\widehat{\bar{K}}_{t-1}+\frac{1-\varphi}{\varphi} \hat{r}_{t}^{k}
$$

The wages are set as in SW (2003). The agent provides a differentiated labor service in the factor market and has monopoly power. If $\theta_{W} \in(0,1)$ is the Calvo parameter for nominal wage stickiness, $\sigma_{N} \geqslant 0$ is the reciprocal of the Frisch elasticity of labor and $\chi_{W}>1$ is the elasticity of substitution between labor varieties in the Dixit-Stiglitz aggregate, the wage equation is given by

$$
\begin{aligned}
\hat{w}_{t}= & \frac{\beta}{1+\beta} \mathbf{E}_{t} \hat{w}_{t+1}+\frac{1}{1+\beta} \hat{w}_{t-1}+\frac{\beta}{1+\beta} \mathbf{E}_{t} \hat{\pi}_{H t+1}-\frac{1+\iota_{W} \beta}{1+\beta} \hat{\pi}_{H t}+\frac{\iota_{W}}{1+\beta} \hat{\pi}_{H t-1} \\
& -\frac{\left(1-\beta \theta_{W}\right)\left(1-\theta_{W}\right)}{\theta_{W}\left(1+\sigma_{N} \chi_{W}\right)(1+\beta)}\left[\hat{w}_{t}-\sigma_{N} \hat{N}_{t}-\sigma_{C} \frac{\hat{C}_{t}-\vartheta \hat{C}_{t-1}}{1-\vartheta}-\xi_{C} \widehat{T o T}_{t}\right]+\varepsilon_{t}^{W M}
\end{aligned}
$$

$\iota_{W} \in[0,1]$ is the degree of indexation of wages to lagged inflation in the GDP deflator and $\varepsilon^{W M}$ is a cost-push disturbance that can be interpreted as a shock to the mark-up of the real wage over the marginal rate of substitution between consumption and leisure (in square brackets) and follows an $\operatorname{ARMA}(1,1)$ process defined as $\varepsilon_{t}^{W M}=\rho_{W M} \varepsilon_{t-1}^{W M}+$ $\eta_{t}^{W M}-\nu_{W M} \eta_{t-1}^{W M}$ such that $\nu_{W M} \in[0,1)$.

\footnotetext{
${ }^{7}$ We use the price of domestic output (GDP deflator) as an observed variable in the estimation and hence will focus on the relative price of investment in terms of output (as opposed to consumption). The price index of investment is obtained from the optimization problem of the final goods sector. Unlike SW (2003, 2007), the price of imports and hence the terms of trade affects the relative price of aggregate investment.
} 
Government Spending and Goods Market Clearing Government spending is financed by lump-sum taxes and falls exclusively on the domestic bundle. ${ }^{8}$ We follow the convention in the literature by reducing government spending to a residual shock in aggregate demand that follows $\varepsilon_{t}^{G O V}=\rho_{G O V} \varepsilon_{t-1}^{G O V}+\eta_{t}^{G O V}$.

Equation 16 represents the goods market clearing condition. Output is absorbed by domestic and export sales for consumption and investment, domestic government spending and the cost of capacity utilization. $\Xi_{C}$ and $\Xi_{I}$ indicate the steady-state shares of consumption and investment in output.

$$
\hat{Y}_{H t}=\Xi_{C}\left(1-\xi_{C}\right) \hat{C}_{H t}+\Xi_{I}\left(1-\xi_{I}\right) \hat{I}_{H t}+\xi_{C} \Xi_{C} \hat{C}_{H t}^{*}+\xi_{I} \Xi_{I} \hat{I}_{H t}^{*}+\varepsilon_{t}^{G O V}+\frac{\bar{K}^{k}}{\bar{Y}_{H}} \frac{1-\varphi}{\varphi} \hat{r}_{t}^{k}
$$

Balance of Payments The inter-temporal flow of net foreign assets is determined by

$$
\begin{aligned}
\widehat{N F A}_{t}-\frac{1}{\beta} \widehat{N F A}_{t-1}= & \xi_{C} \Xi_{C}\left(\widehat{N E R}_{t}+\hat{P}_{H t}^{*}+\hat{C}_{H t}^{*}-\hat{P}_{F t}-\hat{C}_{F t}\right) \\
& +\xi_{I} \Xi_{I}\left(\widehat{N E R}_{t}+\hat{P}_{H t}^{*}+\hat{I}_{H t}^{*}-\hat{P}_{F t}-\hat{I}_{F t}\right)
\end{aligned}
$$

The aggregate net-exports to GDP ratio of the Home economy, which subsumes the prices as well as volumes of imports and exports, is given by the right-hand-side of Equation 17. ${ }^{9}$ Net-exports for consumption and investment are each weighted by their respective shares of imports and steady-state shares in GDP. Using the conditional import demand function in Equation 3 (and its foreign analog), the definitions of the consumption- and investment-based real exchange rates and the terms of trade, we can decompose the trade balance into the sum of differences in the consumption and investment levels between the US and the RoW, the real exchange rates and the differential in the terms of trade. Such a disaggregation will aid our analysis of the impact of the various structural shocks on

\footnotetext{
${ }^{8}$ Our decision to abstract from public debt is motivated by the fact that the purely Ricardian agents reduce their current expenditures when there is a rise in government spending, precluding a strong negative impact on the trade balance. The assumption of a balanced budget implies that this paper does not provide an empirical evaluation of the Twin Deficits hypothesis. This view suggests that the deterioration of the trade balance is determined by the lack of saving by the Federal government. See Corsetti and Müller (2006) and the references therein for more details.

${ }^{9}$ The linearized balance of payments is similarly defined, albeit for the aggregate-absorption based trade specification, in Bergin (2006).
} 
each of these components. ${ }^{10}$ Specifically, the trade balance is redefined as

$$
\begin{aligned}
& \widehat{R T B}_{t}=\overbrace{\Xi_{C} \xi_{C}\left(\hat{C}_{t}^{*}-\hat{C}_{t}\right)+\Xi_{I} \xi_{I}\left(\hat{I}_{t}^{*}-\hat{I}_{t}\right)}^{\text {International Relative Absorption }} \\
& +\overbrace{\Xi_{C} \xi_{C}{\widehat{R E R_{t}}}^{C}+\Xi_{I} \xi_{I}{\widehat{R E R_{t}}}^{I}+(\mu-1)\left[\Xi_{C} \xi_{C}\left(1-\xi_{C}\right)+\Xi_{I} \xi_{I}\left(1-\xi_{I}\right)\right]\left(\widehat{T o T}_{t}-{\widehat{T o T_{t}}}^{*}\right)}^{\text {International Relative Prices }}
\end{aligned}
$$

Monetary Policy The model is closed with the monetary authority following a simple empirical Taylor-type rule to set the nominal interest rate, targeting inflation in the GDP deflator and the level as well as changes in output, and is subject to exogenous monetary policy disturbances:

$$
\hat{R}_{t}=\rho_{M O N} \hat{R}_{t-1}+\left(1-\rho_{M O N}\right)\left(\phi_{\pi} \hat{\pi}_{H t}+\phi_{y} \hat{Y}_{H t}\right)+\phi_{\Delta y}\left(\hat{Y}_{H t}-\hat{Y}_{H t-1}\right)+\eta_{t}^{M O N}
$$

\section{Estimation}

\subsection{Data and Estimation Method}

The empirical treatment of the foreign region in the model, the RoW, poses a significant challenge. Long macroeconomic time series are unavailable for high-saving emerging economies as China or the oil-producing economies that have centered in recent debates in the context of the US deficit. This impedes our effort to disentangle the effect of external disturbances on the imbalance. To remedy the lack of data to form the RoW aggregate, we propose an alternative strategy. More specifically, we use the bilateral trade balance between the US and a group of sixteen industrialized economies - Canada, Japan, Korea, the UK and twelve economies from the Euro-Area - as a proxy for the actual US trade balance. Figure 1 compares the constructed intra-OECD trade balance series with the actual non-energy trade balance since the 1980s. Clearly, a trade imbalance prevails even within the industrialized countries, which motivates our decision to use the bilateral trade balance between the US and this group of OECD economies in the estimations. The OECD series tracks the actual non-energy trade balance rather well between the early

\footnotetext{
${ }^{10}$ Alternatively, as in Raffo (2008), we can separate the effects from the net-export volumes $\hat{C}_{H t}^{*}+\hat{I}_{H t}^{*}-$ $\hat{C}_{F t}-\hat{I}_{F t}$ and the net-export prices $\widehat{N E R}_{t}+\hat{P}_{H t}^{*}-\hat{P}_{F t}$. However, this strategy will not highlight the expenditure-switching effect which is part of the demand functions for export and import volumes. This effect is important to our discussion of the dynamics that follows in Section 3.3.3.
} 
1980s through the late 1990s before the omitted economies started to play a dominant role. As can be seen in Table 1, the two series are highly correlated, both in levels and after detrending. Towards the later years of the sample, the disparity between the two series increases even though they continue to display the high cross-correlation, which is what really matters if we want to analyze the cycle of the balance. Time series from the OECD trade-partners are aggregated using time-varying trade-shares to embody the RoW in the empirical analysis. ${ }^{11}$ In a robustness check, we have also employed the actual trade balance in the estimations and obtain similar results (see also Section 4).

To identify the fourteen structural innovations in the theoretical model - $\eta^{T F P}, \eta^{T F P *}$, $\eta^{I N V}, \quad \eta^{I N V *}, \quad \eta^{U I P}, \eta^{T I}, \quad \eta^{T I *}, \quad \eta^{G O V}, \quad \eta^{G O V *}, \quad \eta^{W M}, \quad \eta^{W M *}, \quad \eta^{M O N}, \quad \eta^{M O N *}$ and $\eta^{P P P}$ - an equal number of macroeconomic time series are matched with their analogs in the model. As in JPT (2010), we adjust the data definition of US investment to include changes in inventories and consumer durables while subtracting expenditures on durables from consumption. ${ }^{12}$ The addition of these components to aggregate investment data makes it more volatile and procyclical. Note that due to non-availability of data, we are unable to make similar adjustments to the RoW series on investment and consumption. We use US and RoW series on real consumption, real investment, real GDP, GDP deflator inflation, real wage inflation, and the nominal interest rates along with the net-exports to US GDP ratio and the output-based real exchange rate spanning 1980Q1-2005Q4.

Table 1 provides the unconditional moments of the data. Observe that due to incorporation of the additional components, US investment growth is twice as volatile as the RoW analog. Hence, a qualification to our results is that we may be underestimating the importance of RoW investment disturbances. Table 1 also links each observable (US) series to the analogous variable in the model. The data series on the trade balance is linearly detrended while the interest rates and inflation series are demeaned. All other series enter the estimation in demeaned first-differences. Other particulars about the data are detailed in the Appendix.

We apply the Bayesian estimation methodology employed by SW (2003, 2007) and we refer to the original papers for a detailed description. In a nutshell, the Bayesian paradigm facilitates the combination of prior knowledge about structural parameters with

\footnotetext{
${ }^{11}$ Bergin (2006), Corsetti et al. (2006) and Bussière et al. (2005) are other studies that use multi-country data aggregates in empirical models of the US external balance.

${ }^{12}$ In SW (2003, 2007), durables expenditures are included in the consumption series while the investment series excludes the changes in inventories.
} 
information in the data as embodied by the likelihood function. The blend of the prior and the likelihood function yields the posterior distribution for the structural parameters which is then used for inference. The appendix also provides further technical details on the estimation methodology.

\subsection{Priors}

An overview of our priors can be found in Table 2. The prior distributions given to the estimated structural parameters are comparable to those used in other studies. The parameters that are not estimated are given dogmatic priors at calibrated values. We follow the strategy of Bergin (2006) and Rabanal and Tuesta (2010) in fixing, rather than estimating, the import-shares. We allow for different import-intensities for consumption and investment by computing the means of the shares of imports from annual data over 1980-2005 from the Bureau of Economic Analysis. ${ }^{13}$ We set the import-share for consumption $\xi_{C}$ at 0.023 and the investment analog $\xi_{I}$ at $0.3994 .{ }^{14}$ These values are quite similar to those used by Erceg et al. (2008) in their simulations. Other calibrations are very standard in the literature, e.g. SW (2007).

\subsection{Baseline Results}

\subsubsection{Posterior Estimates}

The medians and the $5^{\text {th }}$ and $95^{\text {th }}$ percentiles of the posterior distributions of the structural parameters are also reported in Table 2. The estimates of the US parameters are in the ballpark of those obtained in SW (2007). The RoW analogs are of comparable magnitudes except for the habit coefficient and price Calvo parameters, which are rather

\footnotetext{
${ }^{13}$ In particular, we refer to Table $2 b$ (U.S. Trade in Goods) from U.S. International Transactions Accounts Data from the BEA website. We define Investment Imports $\equiv$ Non-energy industrial supplies + Capital goods, except automotive + Automotive vehicles, parts and engines + Consumer durables manufactured and Consumption Imports $\equiv$ Consumer goods (nonfood), except automotive + Foods, feeds, and beverages - Consumer durables manufactured. The import-shares are computed by dividing these by aggregate investment and consumption.

${ }^{14}$ The weights that consumption and investment receive in the definition of the trade balance to GDP ratio are not as disparate as these import-intensities might suggest, because consumption is by far the most dominant component of GDP. Specifically, in Equation 17, the weights given to consumption and investment net-exports are given by $\Xi_{C} \xi_{C}=0.0139$ and $\Xi_{I} \xi_{I}=0.0854$.
} 
low at 0.14 and 0.17 respectively. The trade-elasticity at 1.10 , exceeds the estimates of Lubik and Schorfheide (2006), Bergin (2006) and Rabanal and Tuesta (2010), but is below the calibrated value of 2 used in Erceg et al. (2008).

\subsubsection{Determinants of Trade Balance Fluctuations}

To evaluate the relative importance of the shocks embedded in the model, Table 3 shows the variance of the forecast errors of the trade balance at different horizons. For all shocks, we report the mean of the posterior distribution of variance decompositions. For ease of exposition, we have aggregated the contributions of disturbances that are less relevant for the discussion into 'other' US and RoW shocks. The table also reports the forecast errors of some key US macroeconomic variables, i.e. real GDP, consumption and investment as well as the real exchange rate.

The relative contributions of the shocks to variability in US GDP, consumption and investment are comparable to closed-economy studies, for instance JPT $(2010,2011)$ or SW (2007). ${ }^{15}$ The dominant role of PPP shocks to capture real exchange rate fluctuations is in line with the results of Lubik and Schorfheide (2006). Of special interest however is the role of foreign and open-economy shocks for the US business cycle. Overall, these shocks do not seem to explain a lot: the total contemporaneous and long-run contribution to US GDP variability is approximately 5 percent. The role of external shocks in explaining US investment volatility is more relevant, i.e. around 25 percent in the long-run while their contribution to consumption never exceeds 5 percent. On the other hand, when we consider trade balance fluctuations, foreign and open-economy shocks turn out to be very important. In particular, they explain more than half of US trade balance variability at all horizons. Hence, focusing solely on the influence of domestic shocks to study the deterioration of the US trade balance (e.g. Bems et al. 2007), ignores an important source of volatility.

The results reveal that the US trade balance is mainly driven by investment shocks

\footnotetext{
${ }^{15}$ Relative to SW (2007), we find a more important role for investment shocks in explaining the business cycle. JPT (2010) demonstrate that this difference is due to the fact that SW (2007) include (more volatile) durable expenditures in consumption, while excluding the change in inventories from investment, but not from output. It must be noted that JPT (2010) report variance decompositions at business-cycle frequencies. Our results and those of SW (2007) based in the time-domain, even though very related, are not strictly comparable with those of JPT (2010).
} 
whose contemporaneous contribution is approximately 46 percent, a number which even increases to more than 60 percent over longer horizons. Both US and foreign investment disturbances are important. On impact, the US investment shock contributes about 36 percent. The contribution hits a maximum of more than 44 percent at a 1 year horizon and continues to account for more than 35 percent at the ten year mark. The influence of the RoW investment shocks is somewhat weaker. Their immediate impact is slightly above 10 percent, but the contribution rises to more than 25 percent in the long run. Remember, as discussed in Section 3.1, that US investment data is more volatile than the RoW series because it has been augmented with expenditures on consumer durables and inventories in contrast to the RoW investment series. Not surprisingly, the estimated RoW investment innovation is less than half of the US analog (see Table 2) and hence this could explain the lower contribution of the shock to trade balance fluctuations.

Bergin (2006) finds that UIP shocks determine about two-thirds of short-run variation in the external balance (current account). We also find that these shocks have an important influence, but the magnitude is lower. In particular, the UIP shock explains 42 percent of the variability on impact, but the contribution declines to about 30 percent after one year. All other shocks, i.e. domestic and foreign TFP, time-impatience, wage mark-up, monetary and fiscal policy shocks, as well as purchasing power parity innovations, turn out not to matter much for trade balance variability. This finding is particularly striking for neutral TFP shocks given the fact that these disturbances are often considered as being important to understand trade balance movements (e.g. Backus et al. 1994, Kollmann 1998, Bussière et al. 2005 or Corsetti et al. 2006). In our estimations, the US and the RoW TFP shocks together contribute only about 2 percent at all horizons, which contrasts with a contribution to real GDP of about 18 percent after one year and more than 30 percent in the long run. Similarly, time-impatience shocks account for 16 percent of GDP volatility in the very short run, while the contribution to trade balance fluctuations is negligible. Why do investment shocks overwhelmingly dominate the forecast volatility of the trade balance, in contrast to some other disturbances? In the following subsection, we dissect the dynamic responses of the trade balance and its components to understand the mechanisms that strengthen the transmission of investment disturbances as well as those that render other shocks less potent. 


\subsubsection{Impulse Response Analysis}

In Figure 2, we present the dynamic effects of selected structural shocks on the trade balance and its two main elements as described in Equation 18: the impact on international relative absorption as well as the price effect emanating from the real exchange rate and the differential in the terms of trade. The figure also exhibits the impulse response functions for relative consumption and investment absorption. In the discussion, we focus on the impact of US shocks, as the responses induced by the RoW analogs are symmetric with differences only in magnitudes. All other results are available upon request.

Neutral Technology (TFP) and Investment Shocks The dotted lines and shaded areas in the top panel of Figure 2 represent the 90 percent posterior probability regions of the estimated responses induced by a TFP and an investment shock respectively. On the domestic front, not shown in the figures, the responses to both shocks are in line with the existing literature (e.g. SW 2007 or JPT 2010). A rise in US TFP draws positive responses from consumption, investment and output as the permanent income of the agents rise. The rise in US consumption leads to a significant but small decline in relative consumption absorption while relative investment absorption does not react significantly on impact, but worsens in the medium- and long-run (see second row in Panel 1). In sum, the overall absorption effect is insignificant on impact and becomes mildly negative after about 5 years. On the other hand, the TFP shock results in a deterioration of the US terms of trade and a depreciation of the dollar which is driven by a fall in domestic inflation and interest rate. This positive relative price effect dominates in the short run. The trade balance improves on impact and remains positive for about 5 years, before the effect of the terms of trade weakens and the fall in relative absorption begins to dominate.

An investment shock accelerates the conversion of the investment good into the capital stock and raises the demand for both US and imported intermediate goods. US investment rises strongly on impact without a commensurate increase in output. Whereas the response of consumption is insignificant on impact, it rises persistently after a year. Since consumption - the major component of absorption of US output - does not move significantly in the short-run, the rise in investment demand is not potent enough to raise domestic prices (GDP deflator). However, the price of imports rises strongly, worsening the US terms of trade. Simultaneously, the currency depreciates in real terms and together with the terms of trade effect, exerts a positive influence on the trade balance, much like 
what we observe for the TFP shock.

However, the crux of the differential impact between the investment shock and the TFP shock lies in the ability of the former to elicit a strong negative response from international relative absorption. On impact, both consumption and investment fall slightly in the RoW while RoW output rises to feed the US investment boom (not exhibited). Combined with the rise in US investment, this decreases international relative investment absorption considerably while the fall in the consumption analog is very mild. In sum, international relative absorption falls many times more than in the case of the TFP shock. More precisely, even though the TFP shock raises domestic absorption, the reaction from relative absorption is very weak and the overall influence on the trade balance is determined by the positive effect of the currency depreciation and the terms of trade induced by the fall in the price of US goods. As we noted above, this effect even makes the trade balance behave procyclically in the short- and medium-run. The procyclicality of the trade balance runs against the received wisdom in the literature, e.g. Backus et al. (1994), Kollmann (1998) and Raffo (2008), that emphasizes its counter-cyclical nature. In contrast, the rise in US investment induced by the investment shock is robust enough to dominate the positive effect from the relative prices, generating a decline in the trade balance.

The strong and dominating relative absorption effect for the overall impact of an investment shock on the trade balance is not a surprise. As documented by Erceg et al. (2008), US exports and imports are heavily concentrated in capital goods and consumer durables. Hence, a domestic or foreign shock that raises investment has a much larger effect on the US trade balance than a shock that boosts consumption with a similar magnitude, a mechanism which actually holds for all kind of shocks as we will further demonstrate below. The counter-cyclical trade balance dynamics that the investment shock triggers makes it more appealing than the TFP shock as a stochastic driver of trade deficits.

Time-Impatience and UIP Shocks The dynamic effects for a time-impatience shock and a (negative) UIP shock are plotted in the lower panel of Figure 2. Due to the strong home-bias in consumption, a time-impatience shock increases the demand for the domestic good resulting in a rise in the GDP deflator while the import-prices fall due to the crowding-out of investment which dominates international trade. Hence, the terms of trade improves. In addition, the real exchange rate appreciates due to an interest rate tightening by the monetary authority. Unlike the TFP and investment shocks described above, both 
effects deteriorate the trade balance but the magnitude is extremely mild. The overall impact of the time-impatience shock on the trade balance is also negligible as the relative absorption effect is very small. In particular, a time-impatience shock raises consumption and output while crowding-out investment. Due to the high share of investment goods in international trade, as described earlier, the sharp decline in net absorption of consumption goods is fully compensated by a rise in relative investment absorption (see second row of Panel 2). This explains why time-impatience shocks could be irrelevant for fluctuations in the trade balance, even while being important for domestic GDP variability.

This contrasts with the role of the UIP shock, which is the second most important shock in the variance decomposition of the trade balance. A negative UIP shock, which can be interpreted as a fall in the risk premium on foreign borrowing, creates a wedge between the two nominal interest rates, lowering the US interest rate and raising the RoW analog while also appreciating the dollar in nominal terms. The fall in the home interest rate increases US consumption and investment while the RoW analogs decrease as a consequence of the rise in the RoW interest rate. Relative absorption in both consumption and investment declines, but the latter much more strongly than the former. Due to the high weight of investment goods in overall trade, aggregate relative absorption decreases considerably. The movements are further reinforced by the strong shift in the exchange rate and the relative terms of trade. In effect, the US trade balance deteriorates significantly.

\section{Interpretation and Sensitivity Analysis}

In this section, we inspect the underlying sources of the investment shocks in more detail and examine which features of the model are crucial to explain the differences of our results relative to the existing literature. The outcome of this analysis is summarized in Table 4, which reports the variance decompositions at a 4 quarter forecast horizon for the trade balance. We compare the parameter estimates for each specification to our baseline results in Table 5 . In additional robustness checks which are not reported in this paper, we consistently find a dominant role for investment shocks when we (a) use the actual aggregate or non-energy trade balance (b) use alternative sample periods or trade balance detrending methods (d) remove variable capacity utilization from the model (e) assume complete markets instead of incomplete markets (f) use import-adjustment costs (g) add or remove other shocks and data series to the baseline model. The details of these 
sensitivity checks are available on request.

\subsection{Understanding Investment Disturbances}

It has been customary in the empirical DSGE literature, e.g. Rabanal and Tuesta (2010), Christoffel, Coenen and Warne (2008) and De Walque, Smets and Wouters (2005), to label the investment disturbance in Equation 12 as an investment-specific technology shock, and hence relate it to the inverse of the relative price of investment goods in the sense of Greenwood et al. (1997). ${ }^{16}$ Like in our baseline estimation, these studies do not use the price of investment goods in their estimation and instead identify the investment shock from quantity data.

JPT (2011) report, however, that estimates of the investment shock are much more volatile and only weakly correlated to available measures of the relative price of investment. ${ }^{17}$ Hence, they extend the analysis by allowing investment efficiency to emanate from two stochastic sources. One shock reflects technological improvements that accelerates the production of investment goods and is reflected by a fall in the relative price of investment, as in Greenwood et al. (1997). The second disturbance increases the efficiency of the conversion of finished investment goods into the economy's stock of productive physical capital and does not originate from a fall in investment prices. JPT (2011) label the former category of shocks as 'investment-specific technological' disturbances, and the latter as 'marginal efficiency of investment' shocks.

To refine our understanding of the links between the sources of investment efficiency and movements in the trade balance, we now introduce the two distinct investment disturbances into our open-economy framework. We follow Basu and Thoenissen (2011) in allowing for an $\mathrm{AR}(1)$ technological disturbance $\varepsilon^{I S T}$ to stimulate the investment CES aggregator function: $I_{t}=\varepsilon_{t}^{I S T} F\left(I_{H t}, I_{F t}\right)$ where $F()$ is the aggregator function. In con-

\footnotetext{
${ }^{16}$ However, Guerrieri, Henderson and Kim (2010) demonstrate that the exact inverse relationship is violated when production functions differ across competitive sectors specializing in the production of consumption and investment goods in a closed economy. JPT (2011) show how the equality is disturbed by sector-specific mark-ups under imperfect competition. The relationship also breaks down in an openeconomy setting as the terms of trade enters the definition of the relative price of investment (See Equation $20)$.

${ }^{17}$ In an open-economy context, Mandelman et al. (2011) also document the inability of investmentspecific shocks used in standard models to replicate the properties of the relative price of investment goods in the data.
} 
trast, no similar shock affects the consumption aggregator. The relative price of aggregate investment in terms of domestic output is then negatively related to the investment-specific technological shock.

$$
\hat{P}_{I t}-\hat{P}_{H t}=\xi_{I} \widehat{T o T}_{t}-\hat{\varepsilon}_{t}^{I S T}
$$

On the other hand, the marginal efficiency of investment shock, $\varepsilon^{M E I}$, is an AR (1) process that enters the capital accumulation constraint of the economy which transforms finished investment goods into capital ready for production.

$$
\widehat{\bar{K}}_{t}-(1-\delta) \widehat{\bar{K}}_{t-1}=\delta \hat{I}_{t}+\delta \psi(1+\beta) \hat{\varepsilon}_{t}^{M E I}
$$

In this set-up, the two investment disturbances enter the optimality condition for investment in the following manner:

$$
\hat{I}_{t}=\frac{\beta}{1+\beta} \mathbf{E}_{t} \hat{I}_{t+1}+\frac{1}{1+\beta} \hat{I}_{t-1}+\frac{1}{\psi(1+\beta)}\left(\widehat{T Q}_{t}-\left\{\xi_{I} \widehat{T o T}_{t}-\hat{\varepsilon}_{t}^{I S T}\right\}\right)+\hat{\varepsilon}_{t}^{M E I}
$$

It can easily be seen that the investment shock $\varepsilon^{I N V}$ in our baseline model is a linear combination of the two shocks in Equation 22. Empirically, $\varepsilon^{I S T}$ is disciplined by the use of time series on the price of investment goods in the estimation, while $\varepsilon^{M E I}$ can freely adjust to fit the investment quantity series. Column 2 of Table 4 summarizes the estimation results for this specification. Clearly, the $\varepsilon^{M E I}$ component, rather than the purely investment price-related $\varepsilon^{I S T}$ component, determines the influence of the investment shocks on the trade balance that we observed in the baseline estimation. ${ }^{18}$ In particular, the marginal efficiency shocks dominate the decomposition of the trade balance, contributing more than two-thirds of the variance much like the 'combined' investment shock in the baseline model, whereas the purely technological $\varepsilon^{I S T}$ shocks contribute less than 1 percent.

Our results for the trade balance run parallel to the closed-economy results of JPT (2011), that emphasize a similarly vast disparity in the strength of the two shocks in the variance decomposition of US GDP. ${ }^{19}$ JPT (2011) interpret the $\varepsilon^{M E I}$ shock as a proxy for the efficiency of the latent financial sector in channelling the flow of household savings

\footnotetext{
${ }^{18} \mathrm{An}$ additional insight that emerges from this specification is that while the $\varepsilon^{I S T}$ shock decreases the relative price of investment, the $\varepsilon^{M E I}$ shock raises it due to a rise, i.e. a deterioration, of the domestic terms of trade (not exhibited). The terms of trade worsens as the marginal efficiency shock increases the price of imports while the response of the price of domestic output is insignificant because home consumption is crowded out by shocks to investment. See also Basu and Thoenissen (2011).

${ }^{19}$ Our results for US GDP (not exhibited) in this specification are very similar to JPT (2011).
} 
into new capital. In particular, they draw parallels between the expansionary effect of $\varepsilon^{M E I}$ on the supply curve of capital and similar effects of entrepreneurial net-worth in the agency cost model of Carlstrom and Fuerst (1997). In empirical support of their interpretation, JPT (2011) report that their estimate of $\varepsilon^{M E I}$ is highly correlated to a data-based measure of the external finance premium - the excess of the interest rate paid by entrepreneurs over the risk-free rate. They observe that typically in periods when the functioning of the financial markets is impaired - i.e. the external finance premium is high and net-worth is low- the estimated $\varepsilon^{M E I}$ innovation is negative.

Another sensitivity check also points towards a relevant role of shocks with a financial interpretation for trade balance volatility. Column 3 of Table 4 displays the results for a specification where we remove the time-impatience shock of the baseline estimation and replace them by a risk-premium shock that reduces the interest rate that the agent faces, as in SW (2007). Unlike time-impatience shocks which raise consumption and crowdsout investment, risk-premium shocks enter the Euler equations for both consumption and capital (i.e. Tobin's Q). The additional effect helps the shock to generate a positive comovement between consumption and investment. In particular, a favorable shock decreases the required return on assets which raises current consumption. At the same time, the shock reduces the cost of capital and increases the value of capital and investment. As can be seen in the table, the contribution of these shocks comes to about 20 percent, in stark contrast to the time-impatience shocks that contribute less than 0.5 percent in the baseline case. An examination of the impulse responses (not exhibited) reveals that in both regions, the risk-premium shock induces stronger responses in investment than in consumption. This is not surprising given the well-known higher sensitivity of investment to changes in the real interest rate (that the risk-premium shock augments). Coupled with the higher import-intensity of investment, the rise in domestic absorption stimulates a fall in the trade balance.

\subsection{Bridging the Results with Existing Studies}

We now examine why our results differ from those of Bergin (2006) and De Walque et al. (2005), our precedents in the empirical open-economy literature who find no substantive effect of investment-specific shocks on US trade balance fluctuations, albeit for contrasting reasons. An important caveat to this exercise is that none of the modelling approaches are nested in each other in terms of either structural features or estimation, and it is not our 
intention to replicate their results. However, the checks may still indicate the potential sources of discrepancy.

Bergin (2006) uses maximum likelihood techniques to estimate a symmetric twocountry model using five structural shocks and observable data series for the US and a rest of the G-7 aggregate. Unlike other empirical open-economy studies, he allows the UIP innovation to be correlated to other structural innovations in the model and finds that UIP shocks are the main drivers of the US current account, contributing nearly two-thirds of the short-run volatility, which decreases to a third in the long-run. Home-bias shocks also contribute close to 30 percent in the long run. When he orthogonalizes the covariance matrix, taste shocks dominate the volatility of the trade balance. De Walque et al. (2005) examine the US and Euro-Area trade balances in a large-scale two-country model estimated with Bayesian methods employing twenty-two macroeconomic time series. Unlike us, they find that investment shocks contribute less than 3 percent.

First, both studies use the popular aggregation set-up as seen in Backus et al. (1994), henceforth BKK, so that the share of imports in the final good sector is specified in terms of total absorption $(Y)$. The trade balance is then given as

$$
\widehat{R T B}_{t}=\xi\left(\hat{Y}_{t}^{*}-\hat{Y}_{t}\right)+\xi \widehat{R E R}_{t}+(\mu-1) \xi(1-\xi)\left(\widehat{T o T}_{t}-{\widehat{T o T_{t}}}^{*}\right)
$$

The fourth column of Table 4 shows the variance decomposition of the trade balance for this specification when we fix the import-share of aggregate absorption $\xi$ at 0.15 as in BKK. As can be seen, this assumption reduces the contribution of investment shocks to approximately 36 percent, while UIP shocks become almost equally potent. Interestingly, we also observe a rise in the contribution of all other disturbances in the model. For instance, time-impatience shocks now contribute about 9 percent to trade balance variability. This is not a surprise since the BKK aggregator does not distinguish between final investment and consumption goods, whereas our model allows investment to be more open to imports than consumption. Hence, shocks that mainly influence consumption become relatively more important, in contrast to shocks that affect investment directly.

In contrast to our case, Bergin (2006) has a home-bias shock in his model that directly affects the import-share in the Armington aggregator. The contribution of investment shocks is however hardly affected when we introduce a relative US home-bias shock in the baseline model (not exhibited). ${ }^{20}$ More importantly, Bergin (2006) does not use investment

\footnotetext{
${ }^{20}$ In this case, we have removed the PPP shock from the baseline model to maintain strict equality
} 
shocks, which motivates our decision to also estimate a smaller version of our model abstracting from investment shocks and data. We use the BKK trade specification along with the home-bias shock, while removing many other frictions (e.g. habit persistence, wage rigidities) and shocks to enable a closer comparison with the small-scale set-up that he employs. Subsequently, we use data on output, inflation and interest rate for the US and the RoW together with the intra-OECD trade balance and exchange rate. ${ }^{21}$ The corresponding shocks we employ are those to UIP, the home-bias shock and the home and foreign TFP, time-impatience and monetary policy shocks. As presented in the fifth column of Table 4, the UIP and the time-impatience shocks contribute about 30 and 52 percent respectively while the home-bias shock contributes about 16 percent. Over the 10 year horizon (not exhibited), the UIP shock is the single most important shock contributing nearly 43 percent. This exercise suggests that, when investment-specific shocks are omitted from the analysis, the contribution of these shocks to the trade balance is mainly absorbed by UIP and consumption shocks in the spirit of Bergin (2006). This proposition is confirmed when we re-estimate the Bergin-type smaller specification adding only investment data and investment shocks. As shown in Column 6 of Table 4, the investment shock becomes again the most important determinant, contributing about 40 percent.

What explains the difference with De Walque et al. (2005)? The answer may partly lie in the other shocks used by these authors as well as the assumed degree of openness. First, the De Walque et al. (2005) model uses risk-premium shocks that generate a positive comovement between consumption and investment. As discussed in Section 4.1, these shocks contribute significantly to the forecast variance of the trade balance. Furthermore, unlike this paper, De Walque et al. (2005) do not consider the bilateral balance between the two regions in the model and focus on the actual trade balances instead. In their trade structure, aggregate US (Euro-Area) exports are demanded by the Euro-Area (US) and an unmodelled Rest of the World that is captured through export-demand shocks. Naturally, these export-demand shocks enter the definition of the US trade balance. They find that this shock accounts between 40 and 65 percent of trade balance volatility.

To analyze the role of this omitted RoW export-demand shock more carefully, we

between the number of observables and shocks. The home-bias shock then captures 13 percent of overall trade balance variability at the 1 year horizon. On the other hand, the contribution of UIP shocks declines to 19 percent, while investment shocks still contribute approximately 64 percent.

${ }^{21}$ The share of imports is set at 0.20 as in Bergin (2006). He employs the variables in country-differences. 
have also estimated a model with the BKK aggregate absorption-based trade specification together with an additional demand shock for US exports that acts as the US trade balance's own driving force. The seventh column of Table 4 shows the results when we still assume an import-share of 15 percent in GDP. In this case, the export-demand shock is already an important shock contributing about 27 percent of the forecast variance while the investment shocks contribute 28 percent and UIP shocks nearly 25 percent. However, the decomposition changes dramatically when we estimate the import-share as in De Walque et al. (2005). They use a very restrictive prior centered on the share of 5 percent that is accounted by European exports in US GDP and their posterior estimates are exactly the same as the prior. In contrast, we assigned a relatively loose prior for this parameter and the posterior estimate is close to 2 percent. As one can observe in the last column of Table 4, the export shock now contributes 78 percent of the forecast variance at the 1 year horizon. The main reason is that the very low import-share makes the two regions behave almost as autarkic economies. The trade balance becomes a disconnected variable driven most potently by its own shock, with the more fundamental shocks having a minimal relative impact. Justiniano and Preston (2010) note that the openness parameter can reduce to unrealistic values if left unrestricted in an estimation exercise. Since the import-share of 2 percent obtained in this experiment is much lower than the unconditional import-share of about 15 percent observed in US data, it is hard to recognize the nonstructural export demand shock as the dominant source of trade balance fluctuations. Openness clearly matters in the transmission of fundamental domestic disturbances to the external position.

\section{Conclusions}

This paper has highlighted the influence of investment efficiency shocks, relative to other structural shocks used in the literature, on the bilateral trade balance between the US and a trade-weighted aggregate of sixteen OECD economies in a two-country DSGE model estimated with Bayesian methods. The relative strength of the investment efficiency shock, which holds through a wide array of model specifications, is primarily due to its strong impact on international relative absorption. The negative effect that the US investment shock exerts on international relative absorption dominates the positive influence of expenditureswitching in favor of US exports arising from a deterioration of the US terms of trade. 
In contrast, neutral technological shocks have a much lower influence on trade balance dynamics as a negative impact of rising domestic absorption is dominated by a positive influence from expenditure-switching. The latter effect is strong enough to induce procyclicality in the trade balance.

A further decomposition of the stochastic sources of investment efficiency emphasizes the importance of marginal efficiency of investment shocks rather than traditional investment-specific technology shocks, for trade balance fluctuations. Marginal efficiency of investment shocks are typically interpreted as reduced-form indicators of changes in the efficiency of the financial intermediation process. A promising avenue for future empirical research is hence, endogenizing financial intermediation in the open economy and employing related data series and shocks in a full-information estimation exercise as ours. For instance, Christiano, Motto and Rostagno (2010) report that the explanatory power of investment efficiency shocks is lowered when structural shocks that affect the financial sector are introduced in closed-economy estimations for the US and Euro-Area. Clearly, pinpointing the sources of the alterations to investment frictions is key to better understand the dynamics of the US trade balance.

\section{A Appendix}

\section{A.1 Data Series}

All raw series are seasonally adjusted by the Census X12 method. We use the Direction of Trade Statistics (DOTS) database of the International Monetary Fund (IMF) to construct the annualized aggregated bilateral trade balance (net-exports in US dollars) between the US and the 16 OECD trade partners over 1980Q1-2005Q4. The series for nominal GDP, nominal consumption, nominal gross fixed capital formation, nominal interest rates, nominal wages and nominal exchange rates for the US, Canada, Japan, Korea and the UK are obtained from the International Financial Statistics Database (IFS) of the IMF. For the Euro-Area series, we use data from the Area Wide Model (Fagan et al. 2001). ${ }^{22}$ The series for consumer durables for the US is drawn from the FRED II database of the

\footnotetext{
${ }^{22}$ We use the best available substitutes for the nominal interest rate for each economy. For Canada and the United Kingdom, we use the Treasury Bill rate, for Japan we use the government bond yield, and for Korea, we use the discount rate. Finally, the nominal interest rate series (STN) from the Area Wide Model is used.
} 
Federal Reserve Bank of St.Louis and the series on changes in US inventories is from the IFS. As mentioned in the main text, we add consumer durables and inventories to the US series on gross fixed capital formation while subtracting expenditure on durables from US consumption. We use the gross private domestic investment deflator series from the Bureau of Economic Analysis while the investment deflators for the trade partners are drawn from the OECD Quarterly National Accounts database and the Area Wide Model. Shares of each individual economy are computed by dividing the sum of imports and exports with the individual economy by aggregate trade. We use these time-varying weights to aggregate individual economy series to make the RoW (Canada generally gets the highest weight while Korea gets the lowest). The trade-share weights are also used to construct a bilateral nominal exchange rate between the US and the RoW, which exhibits a correlation coefficient of 0.81 with the IMF's Nominal Effective Exchange Rate. ${ }^{23}$ We multiply the natural logarithms of real consumption, real GDP, real investment, the investment deflator, the GDP deflator, the real wage and the GDP-deflator based real exchange rate by 100 . These series are fed into the model in demeaned first differences. The demeaned nominal interest rates are divided by 4 to translate them into quarterly terms. The nominal interest rates and the linearly detrended trade balance to US GDP ratio enter the estimation in levels.

\section{A.2 Estimation}

We use 525000 iterations of the Random Walk Metropolis Hastings algorithm to simulate the posterior distributions and achieve acceptance rates of about 40 percent in all our specifications. We monitor the convergence of the marginal posterior distributions using CUMSUM statistics as defined by Bauwens et al. (1999). We discard the initial 25000 draws to compute the posterior moments in each case. The distributions of impulse response functions and variance decompositions that we present are computed from 150 random draws from the posterior. This strategy ensures that our results are not contingent on a particular vector of parameter values such as the posterior median or the mode.

\footnotetext{
${ }^{23}$ The pre-EMU Euro-Dollar exchange rate was constructed using the methodology of Lubik and Schorfheide (2005) harnessing country-weights from the Area Wide Model.
} 


\section{References}

[1] Backus, David, Patrick Kehoe and Finn Kydland, 1994. "Dynamics of the Trade Balance and the Terms of Trade: The J-Curve?". American Economic Review 84, pp.84-103.

[2] Basu, Parantap and Christoph Thoenissen, 2011. "International Business Cycles and the Relative Price of Investment Goods". Forthcoming in the Canadian Journal of Economics.

[3] Bauwens, Luc, Michel Lubrano and Jean-Francois Richard, 1999. "Bayesian Inference in Dynamic Econometric Models". Oxford University Press.

[4] Bems, Rudolfs, Luca Dedola and Frank Smets, 2007. "US Imbalances: The Role of Technology and Policy". Journal of International Money and Finance 26, pp.523-545.

[5] Bergin, Paul, 2006. "How Well can the New Open Economy Macroeconomics Explain the Exchange Rate and Current Account?". Journal of International Money and Finance 25, pp.675-701.

[6] Bussière, Matthieu, Marcel Fratzscher and Gernot Müller, 2005. "Productivity Shocks, Budget Deficits and the Current Account". European Central Bank Working Paper No.509.

[7] Carlstrom, Charles and Timothy Fuerst, 1997. "Agency Costs, Net Worth, and Business Fluctuations: A Computable General Equilibrium Analysis". American Economic Review 87, pp.893-910

[8] Christiano, Lawrence, Roberto Motto and Massimo Rostagno, 2010. "Financial Factors in Economic Fluctuations". European Central Bank Working Paper No.1192.

[9] Christoffel, Kai, Günter Coenen and Anders Warne, 2008. "The New Area-Wide Model of the Euro-Area - A Micro-founded Open-Economy Model for Forecasting and policy Analysis". European Central Bank Working Paper Series 944.

[10] Corsetti, Giancarlo, Luca Dedola and Sylvain Leduc, 2006. "Productivity, External Balance and Exchange Rates: Evidence on the Transmission Mechanism Among G7 Countries". in Lucrezia Reichlin and Kenneth West (Eds.) NBER International Seminar on Macroeconomics. 
[11] Corsetti, Giancarlo and Gernot Müller, 2006. "Twin Deficits: Squaring Theory, Evidence and Common Sense". Economic Policy 48, pp.597-638.

[12] Corsetti, Giancarlo and Panagiotis Konstantinou, 2009. "What Drives US Foreign Borrowing? Evidence on External Adjustment to Transitory and Permanent Shocks". European University Institute Mimeo. http://www.eui.eu/Personal/corsetti/research/USliabilities.pdf

[13] De Walque, Gregory, Frank Smets and Rafael Wouters, 2005. "An Estimated TwoCountry DSGE Model for the Euro-Area and the US Economy". National Bank of Belgium Mimeo. (Version December 2)

[14] Engel, Charles and John Rogers, 2006. "The U.S. Current Account Deficit and the Expected Share of World Output". Journal of Monetary Economics 53, pp.1063-1093.

[15] Erceg, Christopher, Luca Guerrieri and Christopher Gust, 2008. "Trade Adjustment and the Composition of Trade". Journal of Economic Dynamics and Control 32, pp.2622-2650.

[16] Fagan, Gabriel, Jérôme Henry and Ricardo Mestre, 2001. "An Area-Wide Model (AWM) for the Euro-Area". European Central Bank Working Paper No.42.

[17] Fisher, Jonas, 2006. "The Dynamic Effect of Neutral and Investment-Specific Technology Shocks". Journal of Political Economy 114, pp.413-451.

[18] Greenwood, Jeremy, Zvi Hercowitz and Per Krusell, 1997. "Long-Run Implications of Investment-Specific Technological Change". American Economic Review 87, pp.342362.

[19] Guerrieri, Luca, Dale Henderson and Jinill Kim, 2010. "Interpreting Investmentspecific Technology Shocks". International Finance Discussion Papers 1000, Board of Governors of the Federal Reserve System.

[20] Jacob, Punnoose and Gert Peersman, 2008. "Dissecting the Dynamics of the US Trade Balance in an Estimated Equilibrium Model". Faculty of Economics and Business Administration Working Paper No. 08/544, Ghent University.

[21] Justiniano, Alejandro and Bruce Preston, 2010. "Can Structural Small Open Economy Models Account for the Influence of Foreign Disturbances?" Journal of International Economics 81, pp.61-74. 
[22] Justiniano, Alejandro, Giorgio Primiceri and Andrea Tambalotti, 2011. "Investment Shocks and the Relative Price of Investment". Review of Economic Dynamics 14, pp.101-121.

[23] Justiniano, Alejandro, Giorgio Primiceri and Andrea Tambalotti, 2010. "Investment Shocks and Business Cycles". Journal of Monetary Economics 57, pp.132-145.

[24] Kollmann, Robert, 1998. "US Trade Balance Dynamics: The Role of Fiscal Policy and Productivity Shocks and of Financial Market Linkages". Journal of International Money and Finance 17, pp.637-669.

[25] Lubik, Thomas and Frank Schorfheide, 2006. "A Bayesian Look at the New Open Economy Macroeconomics". NBER Macroeconomics Annual 20, pp.313-366.

[26] Mandelman, Federico, Pau Rabanal, Juan Francisco Rubio-Ramirez and Diego Vilan, 2011. "Investment- Specific Technology Shocks and International Business Cycles: An Empirical Assessment". Review of Economic Dynamics 14, pp.136-155.

[27] Rabanal, Pau and Vincente Tuesta, 2010. "Euro-Dollar Real Exchange Rate Dynamics in an Estimated Two-Country Model: An Assessment". Journal of Economic Dynamics and Control 34, pp.780-797.

[28] Raffo, Andrea, 2008. "Net-exports, Consumption Volatility and International Business Cycle Models". Journal of International Economics 75, pp.14-29.

[29] Smets, Frank and Rafael Wouters, 2007. "Shocks and Frictions in US Business Cycles: A Bayesian DSGE Approach". American Economic Review 97, pp.586-606.

[30] Smets, Frank and Rafael Wouters, 2003. "An Estimated Dynamic Stochastic General Equilibrium Model of the Euro-Area". Journal of the European Economic Association 1, pp.1123-1175. 
Figure 1: Comparing the Intra-OECD US Trade to the Aggregate NonEnergy Trade Balance

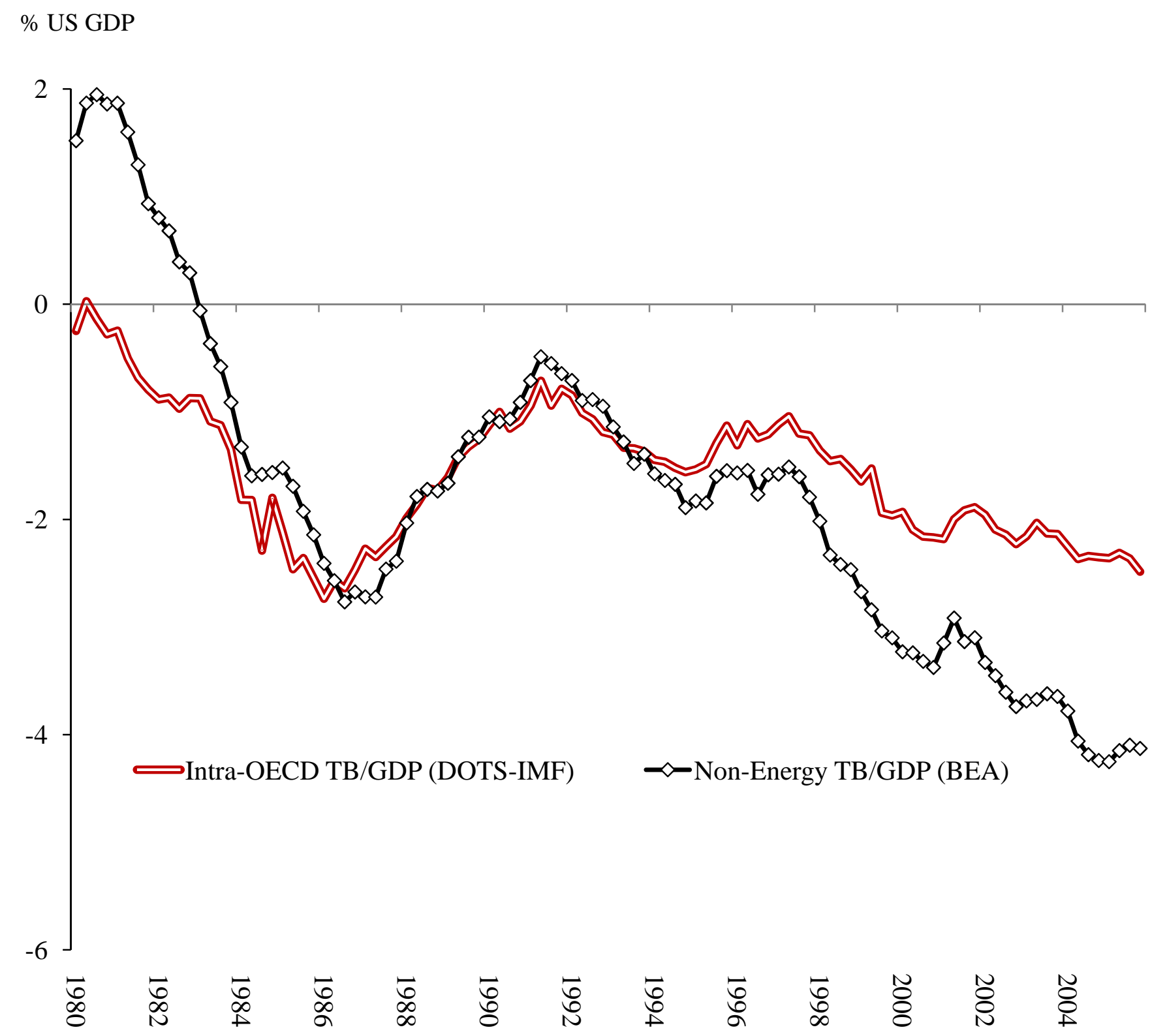

Note: The Rest of the World (RoW) is a trade-weighted aggregate of the United Kingdom, Canada, Japan, Korea and 12 members of the Euro-Area. 


\section{Figure 2: Impulse response functions of some key variables}

Panel 1: $\square$ Investment Shock

ニニニニ Total Factor Productivity Shock

Trade Balance/GDP

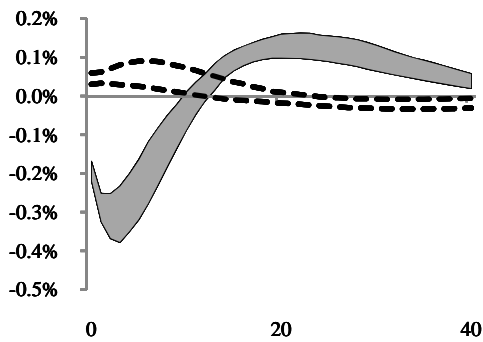

RoW - US Absorption Effect

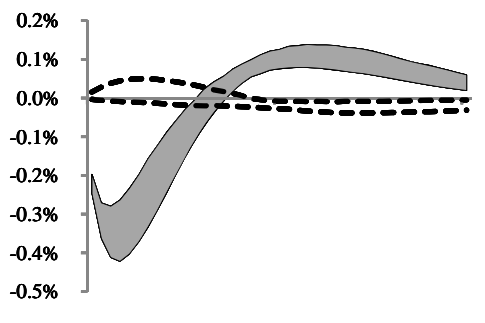

RER + Terms of Trade Effect

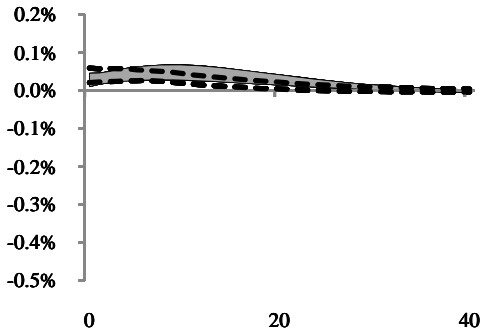

RoW - US Consumption

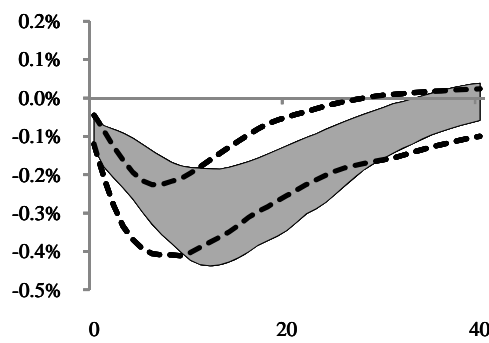

RoW - US Investment

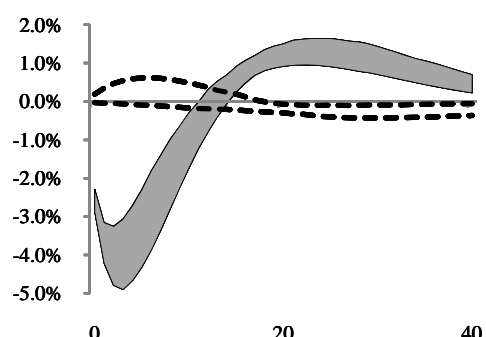

Panel 2: $\quad=$ Consumption Time-Impatience Shock ::::::: Uncovered Interest Parity Shock

Trade Balance/GDP

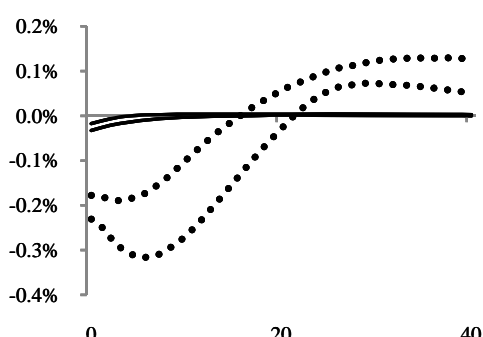

RoW - US Absorption Effect

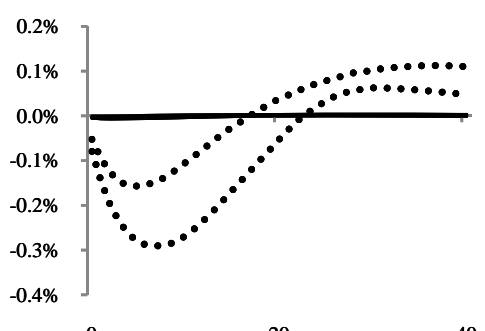

RER + Terms of Trade Effect

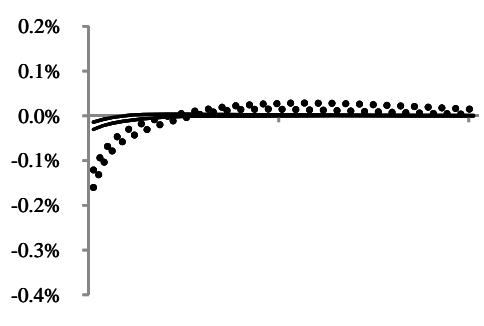

RoW - US Consumption

RoW - US Investment
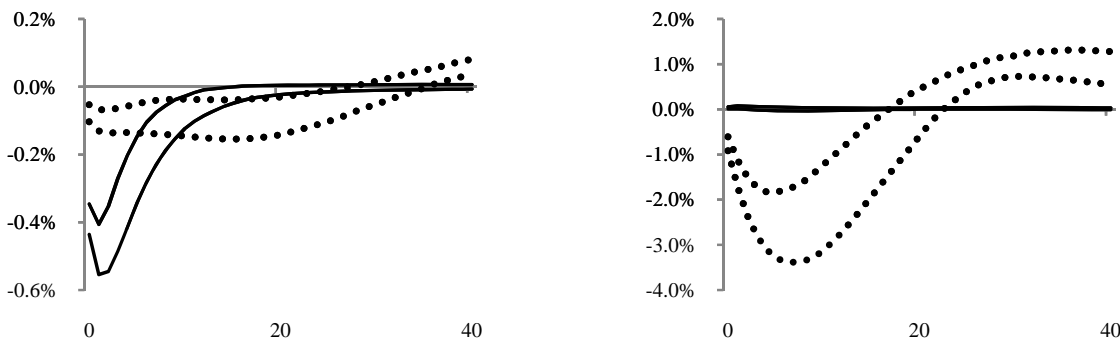

Note: We consider impulse responses for positive one standard deviation shocks in all cases except in the case of the uncovered interest parity shock which is negative. The first row in each panel exhibits the responses of the aggregate US trade balance and those of its two elements: (a) the weighted difference between RoW and US absorption (b) the weighted sum of the influence of the relative terms of trade and the real exchange rates for consumption and investment. The second line in each panel shows the responses of unweighted relative consumption and investment. 
Table 1: Unconditional Moments of the Data

Correlation between the Intra-OECD and the Actual Non-Energy US Trade Balances

Level

Linear Detrending

Observable Series

Intra-OECD TB/GDP
Non-Energy TB/GDP

Real Depreciation of USD

Real Consumption Growth

Real Investment Growth

Real GDP Growth

Nominal Interest Rate

GDP Deflator Inflation

Investment Deflator

Inflation

Real Wage Inflation
0.89

0.96
US

$\underline{\text { RoW }}$

Filter

Model US Variable

Mean $\underline{\text { SD }}$ Mean $\underline{\text { SD }}$

\begin{tabular}{ll|l|}
-1.53 & 0.66 & $-\quad-$
\end{tabular}

\begin{tabular}{ll|ll}
-1.66 & $1.58 \quad-$ & -
\end{tabular}

$-0.03 \quad 2.74 \quad-\quad-$

Demeaned

\begin{tabular}{ll|ll|l}
0.86 & 0.44 & 0.64 & 0.50 & Demeaned
\end{tabular}

$0.61 \quad 2.56$

$\begin{array}{ll}0.60 & 1.27\end{array}$

Demeaned

$0.71 \quad 0.70$

0.65

0.55

Demeaned

$1.66 \quad 0.95$

1.70

0.85

Demeaned

$0.82 \quad 0.53$

0.82

0.78

Demeaned

$0.53 \quad 0.73$

0.62

0.65

Demeaned

$0.26 \quad 0.46$
$\widehat{R T B}_{t}$

$\widehat{R T B}_{t}$

$\Delta \widehat{N E R}_{t}+\hat{\pi}_{F t}^{*}-\hat{\pi}_{H t}$

$\Delta \hat{C}_{\mathrm{t}}+\xi_{C} \Delta \widehat{T o T_{\mathrm{t}}}$

$\Delta \hat{l}_{t}+\xi_{I} \Delta \widehat{T o T}_{t}$

$\Delta \widehat{Y}_{H t}$

$\hat{R}_{t}$

$\hat{\pi}_{H t}$

$\Delta \hat{P}_{I t}$

$\Delta \widehat{w}_{t}$

Note: $\Delta$ indicates the temporal difference operator. We adjust for the terms of trade when we link aggregate consumption and investment to the data. For example, the level of real consumption, as we measure it in the data is given as $C^{D A T A}=\frac{P_{C P I}}{P_{G D P}} C^{M O D E L}$. Thus, because the CPI has a component that depends on the import-intensity $\xi_{C}$, the terms of trade influence real aggregate consumption. As the observables are fed into the model in first differences, the changes in the terms of trade are accounted for. 


\begin{tabular}{|c|c|c|c|c|c|c|}
\hline \multicolumn{3}{|c|}{ ESTIMATED STRUCTURAL PARAMETERS } & \multirow{2}{*}{$\begin{array}{l}\text { Posterior } \\
\text { Med }\left[5^{\text {th }} ; 95^{\text {th }} \% \text { ile }\right]\end{array}$} & \multicolumn{2}{|c|}{ SHOCKS AR(1), MA(1) } & \multirow{2}{*}{$\begin{array}{l}\text { Posterior } \\
\text { Med }\left[5^{\text {th }}, 95^{\text {th }} \% \text { ile }\right]\end{array}$} \\
\hline Symbol & $\underline{\text { Description }}$ & $\underline{\text { Prior }(\mathrm{P} 1, \mathrm{P} 2)}$ & & $\underline{\text { Symbol }}$ & $\underline{\text { Prior }(\mathrm{P} 1, \mathrm{P} 2)}$ & \\
\hline$\mu$ & Trade Elasticity & $\mathrm{G}(1.00,0.05)$ & $1.10[1.03 ; 1.19]$ & $\rho_{T F P}$ & B $(0.50,0.15)$ & $0.94[0.92 ; 0.97]$ \\
\hline$\sigma_{C}$ & US Utility Curvature & $G(2.00,0.75)$ & $2.96[2.08 ; 4.10]$ & $\rho_{T F P}^{*}$ & $\mathrm{~B}(0.50,0.15)$ & $0.95[0.86 ; 0.99]$ \\
\hline$\sigma_{C}{ }^{*}$ & RoW Utility Curvature & $G(2.00,0.75)$ & $2.92[2.26 ; 3.78]$ & $\rho_{I N V}$ & $\mathrm{~B}(0.50,0.15)$ & $0.62[0.49 ; 0.72]$ \\
\hline$\vartheta$ & US External Habit & $\mathrm{B}(0.50,0.15)$ & $0.74[0.58 ; 0.84]$ & $\rho_{I N V}^{*}$ & $\mathrm{~B}(0.50,0.15)$ & $0.79[0.71 ; 0.87]$ \\
\hline$\vartheta^{*}$ & RoW External Habit & $\mathrm{B}(0.50,0.15)$ & $0.14[0.06 ; 0.25]$ & $\rho_{U I P}$ & $\mathrm{~B}(0.50,0.15)$ & $0.87[0.82 ; 0.91]$ \\
\hline$\psi$ & US Investment Adj. Cost & $\mathrm{N}(4.00,1.00)$ & $6.30[4.95 ; 7.72]$ & $\rho_{T I}$ & $\mathrm{~B}(0.50,0.15)$ & $0.52[0.33 ; 0.72]$ \\
\hline$\psi^{*}$ & RoW Investment Adj. Cost & $\mathrm{N}(4.00,1.00)$ & $6.44[5.10 ; 7.82]$ & $\rho_{T I}^{*}$ & $\mathrm{~B}(0.50,0.15)$ & $0.84[0.76 ; 0.90]$ \\
\hline$\varphi$ & US Capacity Util. Cost & $\mathrm{B}(0.50,0.15)$ & $0.63[0.49 ; 0.75]$ & $\rho_{G O V}$ & $\mathrm{~B}(0.50,0.15)$ & $0.91[0.84 ; 0.96]$ \\
\hline$\varphi^{*}$ & RoW Capacity Util. Cost & $\mathrm{B}(0.50,0.15)$ & $0.68[0.48 ; 0.85]$ & $\rho_{G O V}^{*}$ & $\mathrm{~B}(0.50,0.15)$ & $0.93[0.85 ; 0.97]$ \\
\hline$\theta_{P}$ & US GDP Deflator Calvo & $\mathrm{B}(0.50,0.15)$ & $0.76[0.67 ; 0.83]$ & $\rho_{W M}$ & B $(0.50,0.15)$ & $0.59[0.42 ; 0.75]$ \\
\hline$\theta_{P}{ }^{*}$ & RoW GDP Deflator Calvo & $\mathrm{B}(0.50,0.15)$ & $0.17[0.09 ; 0.30]$ & $\rho_{W M}^{*}$ & $\mathrm{~B}(0.50,0.15)$ & $0.88[0.78 ; 0.94]$ \\
\hline$l_{P}$ & US Price Indexation & $\mathrm{B}(0.50,0.15)$ & $0.18[0.08 ; 0.33]$ & $v_{W M}$ & $\mathrm{~B}(0.50,0.15)$ & $0.44[0.24 ; 0.65]$ \\
\hline$l_{P}{ }^{*}$ & RoW Price Indexation & $\mathrm{B}(0.50,0.15)$ & $0.36[0.16 ; 0.64]$ & $v_{W M}^{*}$ & $\mathrm{~B}(0.50,0.15)$ & $0.70[0.47 ; 0.85]$ \\
\hline$\theta_{W}$ & US Wage Calvo & $\mathrm{B}(0.50,0.15)$ & $0.90[0.82 ; 0.95]$ & & & \\
\hline$\theta_{W}^{*}$ & RoW Wage Calvo & $\mathrm{B}(0.50,0.15)$ & $0.69[0.56 ; 0.81]$ & & & \\
\hline$l_{W}$ & US Wage Indexation & $\mathrm{B}(0.50,0.15)$ & $0.71[0.55 ; 0.84]$ & & & \\
\hline$l_{W}^{*}$ & RoW Wage Indexation & $\mathrm{B}(0.50,0.15)$ & $0.13[0.06 ; 0.24]$ & \multicolumn{2}{|c|}{ SHOCK INNOVATIONS } & \\
\hline$\phi_{\pi}$ & US Mon. Pol. (Inflation) & $G(0.50,0.25)$ & $2.12[1.72 ; 2.63]$ & & & \\
\hline$\phi_{\pi}^{*}$ & RoW Mon. Pol. (Inflation) & $G(0.50,0.25)$ & $1.70[1.43 ; 2.08]$ & $100 \sigma^{T F P}$ & $\mathrm{IG}(0.10,2)$ & $0.58[0.43 ; 0.86]$ \\
\hline$\phi_{y}$ & US Mon. Pol. (GDP) & $G(0.50,0.25)$ & $0.07[0.04 ; 0.13]$ & $100 \sigma^{T F P^{*}}$ & IG $(0.10,2)$ & $0.44[0.37 ; 0.56]$ \\
\hline$\phi_{y}^{*}$ & RoW Mon. Pol. (GDP) & $G(0.50,0.25)$ & $0.06[0.02 ; 0.12]$ & $100 \sigma^{I N V}$ & IG $(0.10,2)$ & $0.74[0.60 ; 0.93]$ \\
\hline$\phi_{\Delta y}$ & US Mon. Pol. (GDP change) & $G(0.50,0.25)$ & $0.27[0.22 ; 0.33]$ & $100 \sigma^{I N V^{*}}$ & IG $(0.10,2)$ & $0.27[0.22 ; 0.33]$ \\
\hline$\phi_{\Delta y}{ }^{*}$ & RoW Mon. Pol. (GDP change) & $G(0.50,0.25)$ & $0.27[0.21 ; 0.35]$ & $100 \sigma^{U I P}$ & IG $(0.10,2)$ & $0.35[0.26 ; 0.48]$ \\
\hline$\rho_{M O N}$ & US Interest Smoothing & $\mathrm{B}(0.50,0.15)$ & $0.82[0.77 ; 0.86]$ & $100 \sigma^{T I}$ & $\operatorname{IG}(0.10,2)$ & $0.11[0.07 ; 0.15]$ \\
\hline$\rho_{M O N}{ }^{*}$ & RoW Interest Smoothing & $\mathrm{B}(0.50,0.15)$ & $0.87[0.83 ; 0.90]$ & $100 \sigma^{T I^{*}}$ & $\operatorname{IG}(0.10,2)$ & $0.06[0.04 ; 0.10]$ \\
\hline & & & & $100 \sigma^{G O V}$ & IG $(0.10,2)$ & $0.23[0.20 ; 0.26]$ \\
\hline \multirow{2}{*}{\multicolumn{3}{|c|}{ CALIBRATED STRUCTURAL PARAMETERS }} & & $100 \sigma^{G O V^{*}}$ & IG $(0.10,2)$ & $0.31[0.28 ; 0.36]$ \\
\hline & & & & $100 \sigma^{W M}$ & IG $(0.10,2)$ & $0.13[0.10 ; 0.15]$ \\
\hline$\beta$ & Discount Factor & & 0.99 & $100 \sigma^{W M^{*}}$ & IG $(0.10,2)$ & $0.13[0.10 ; 0.17]$ \\
\hline$\alpha$ & Share of Capital Services in Proc & uction & $1 / 3$ & $100 \sigma^{M O N}$ & $\operatorname{IG}(0.10,2)$ & $0.23[0.20 ; 0.26]$ \\
\hline$\delta$ & Quarterly Rate of Capital Depre & iation & 0.025 & $100 \sigma^{M O N^{*}}$ & IG $(0.10,2)$ & $0.17[0.15 ; 0.21]$ \\
\hline$\chi_{P}$ & Substitution Elasticity of Goods & Varieties & 10 & $100 \sigma^{P P P}$ & IG $(0.10,2)$ & $3.56[3.18 ; 4.01]$ \\
\hline$\chi_{W}$ & Substitution Elasticity of Labour & Varieties & 10 & & & \\
\hline$\sigma_{N}$ & Inverse of Frisch Elasticity & & 2 & & & \\
\hline$\kappa$ & Cost of adjusting foreign assets & & 0.001 & & & \\
\hline$\theta_{H}{ }^{*}$ & US Export Calvo & & 0.5 & & & \\
\hline$\theta_{F}$ & RoW Export Calvo & & 0.5 & & & \\
\hline$\xi_{C}$ & Import-share of consumption & & 0.023 & & & \\
\hline$\xi_{I}$ & Import-share of investment & & 0.3994 & & & \\
\hline$\Xi_{G}$ & Share of government spending ir & GDP & 0.18 & & & \\
\hline$\Xi_{I}$ & Implied share of investment in $\mathrm{C}$ & & 0.2137 & & & \\
\hline
\end{tabular}

Note: $\mathrm{G}=$ Gamma, $\mathrm{B}=$ Beta, $\mathrm{IG}=$ Inverse Gamma and $\mathrm{N}=$ Normal distributions. $\mathrm{P} 1=$ Mean and $\mathrm{P} 2=$ Standard Deviation for all distributions. Posterior moments are computed using 500000 draws from the distribution simulated by the Random Walk Metropolis algorithm. 


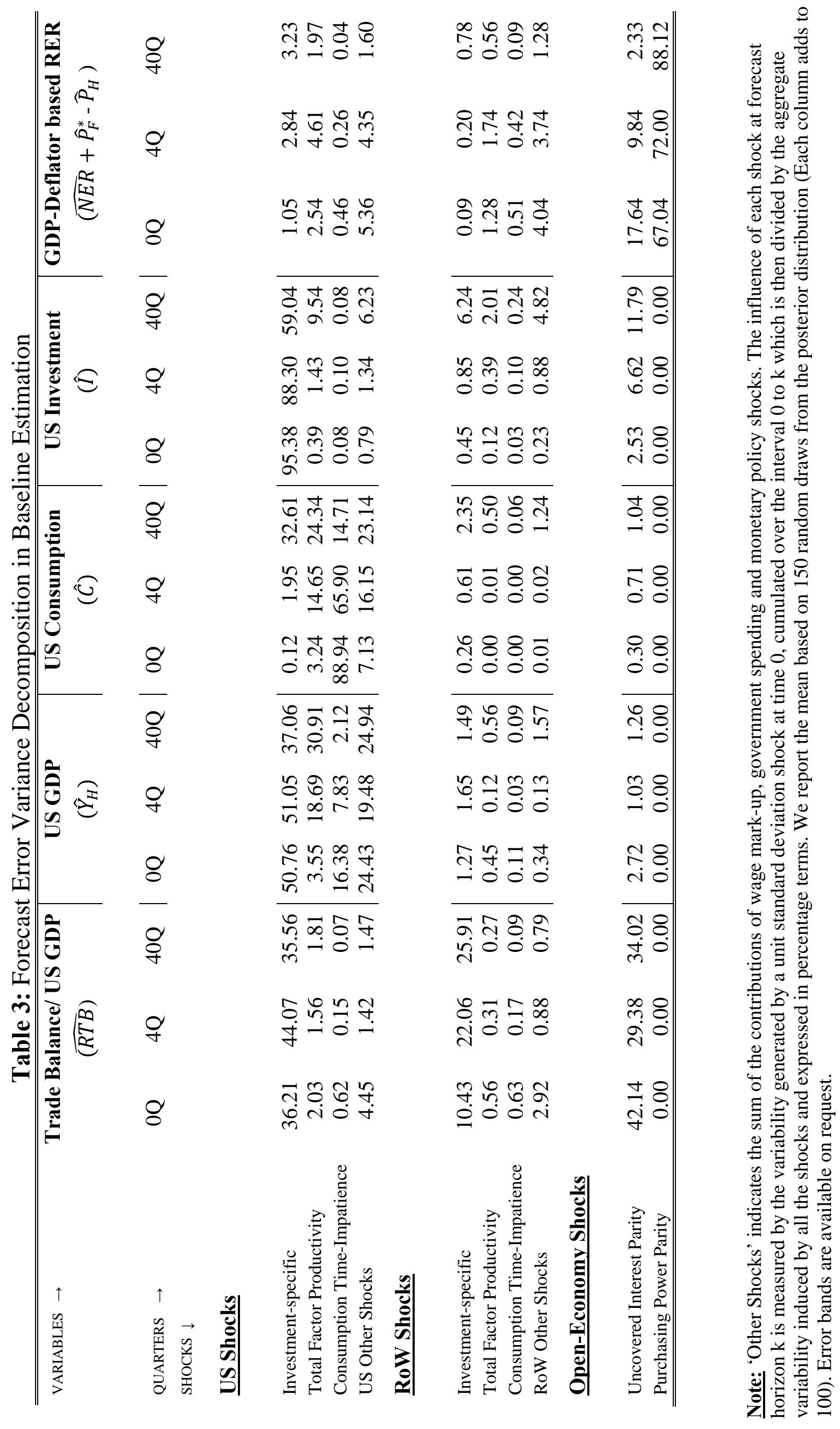




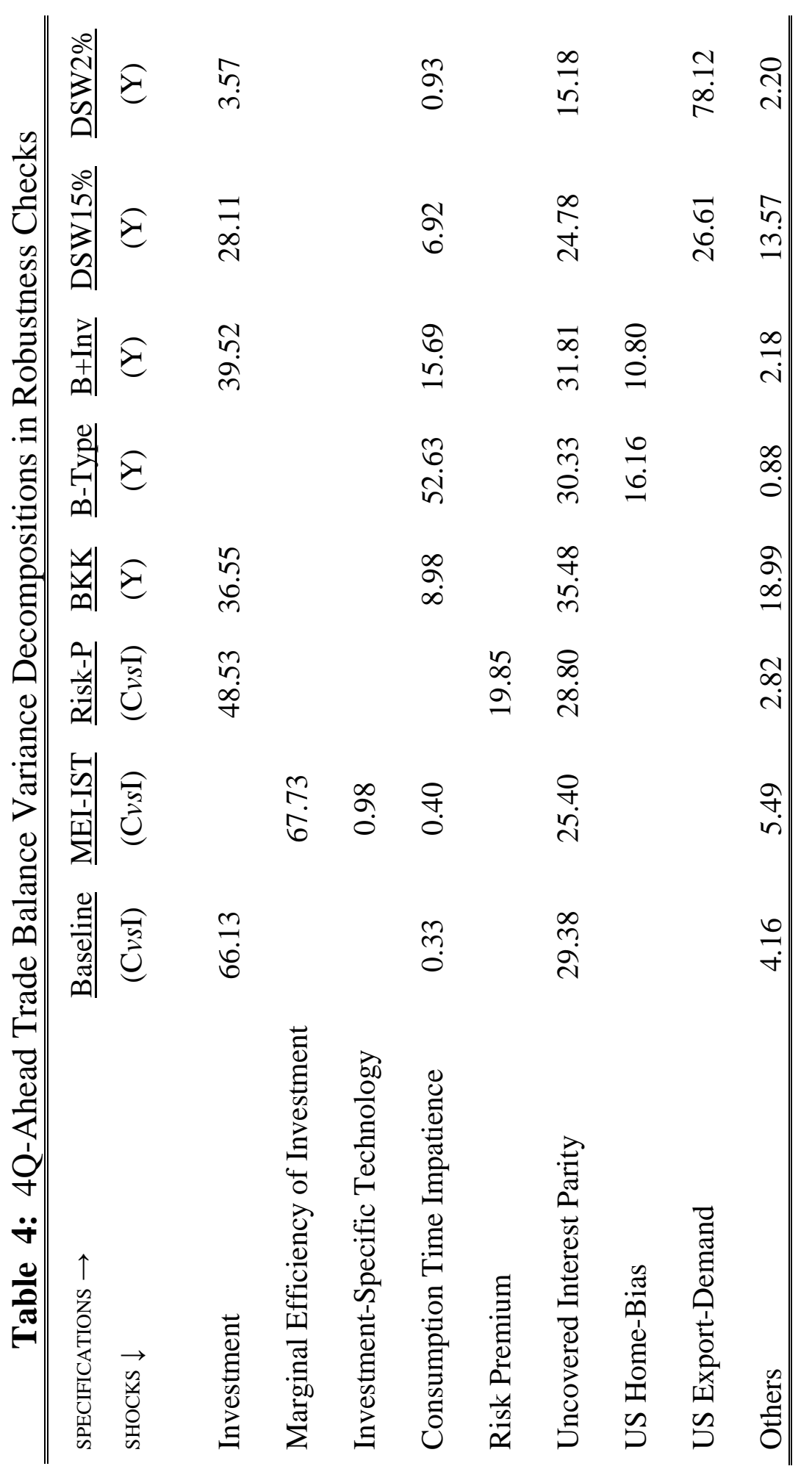

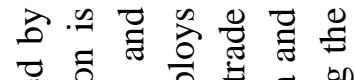

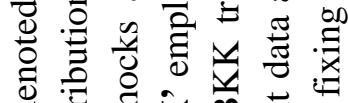

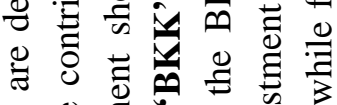

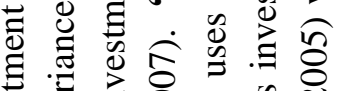

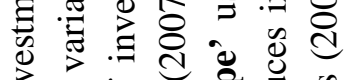

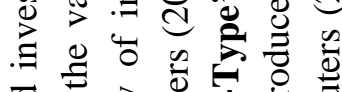

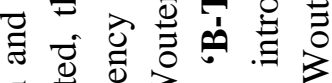

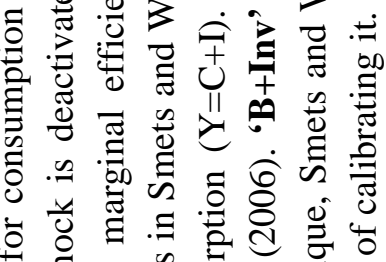

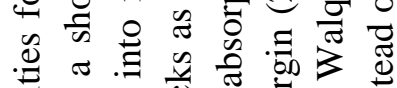

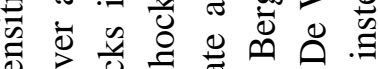

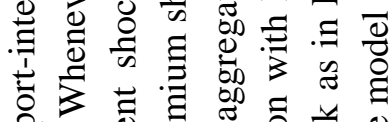

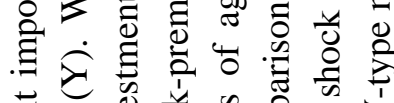

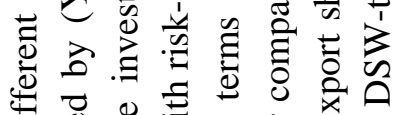

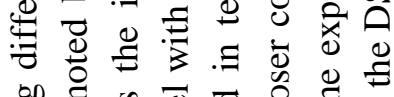

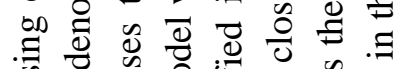
乌

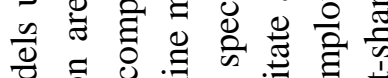

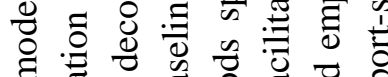

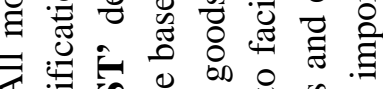

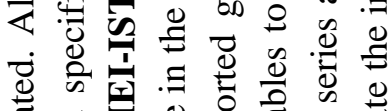

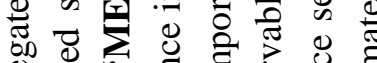

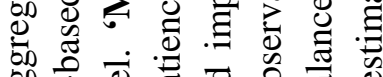

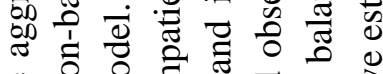

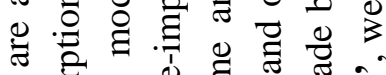

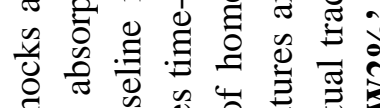

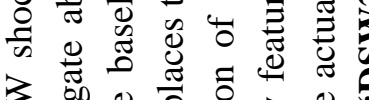
3

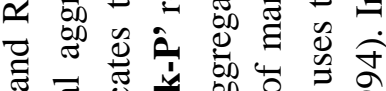
드 चี चٓ s.

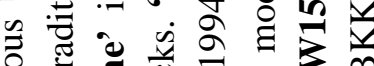

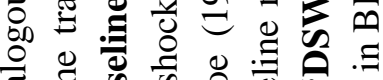

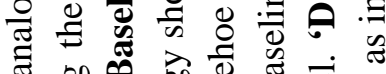
元

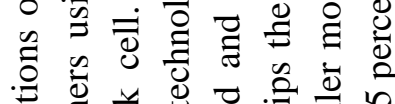

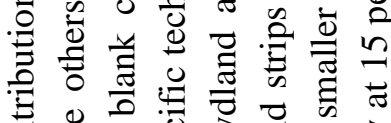

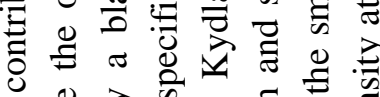

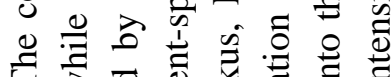

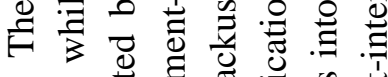

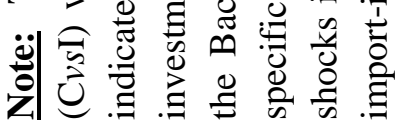




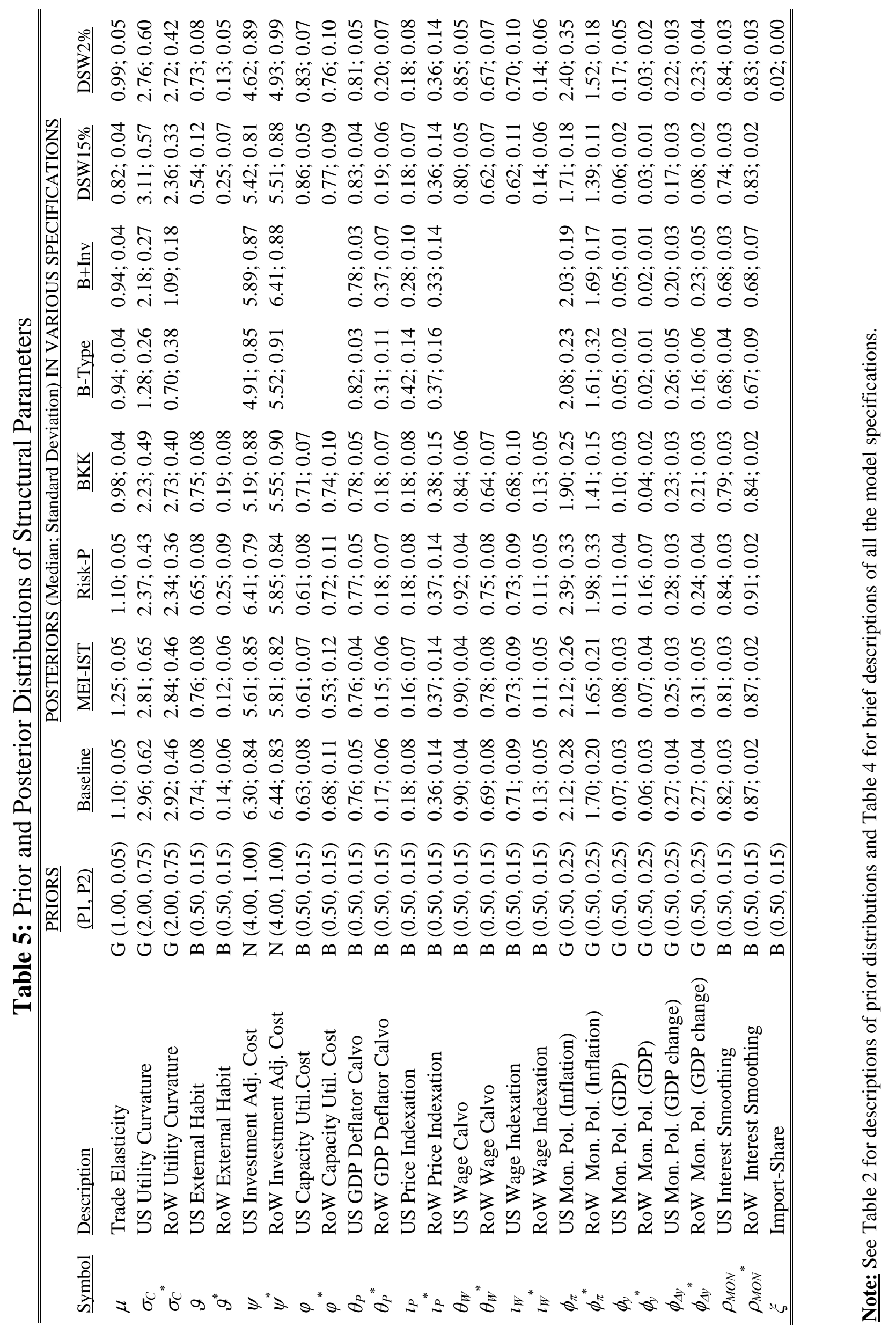




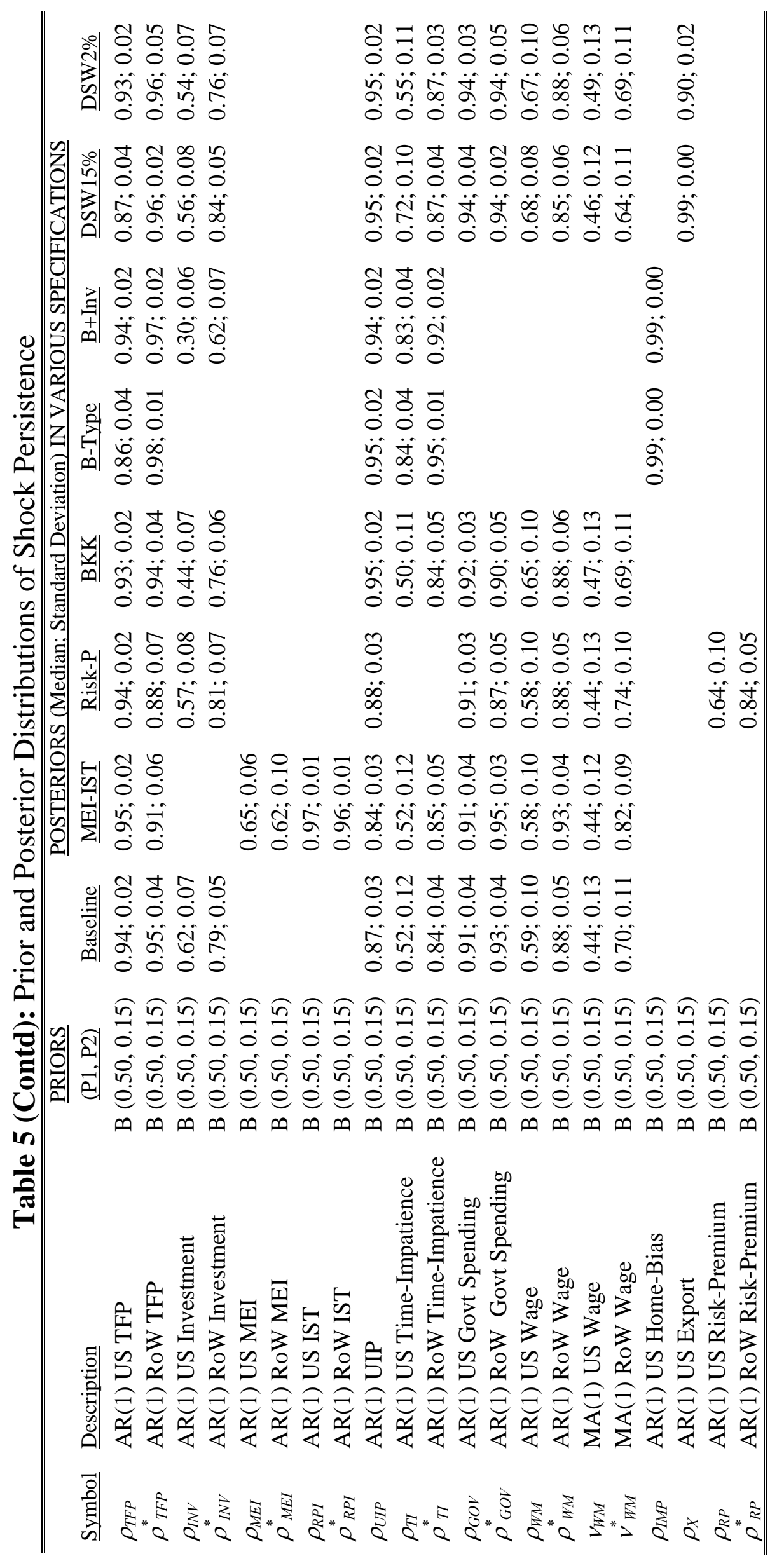




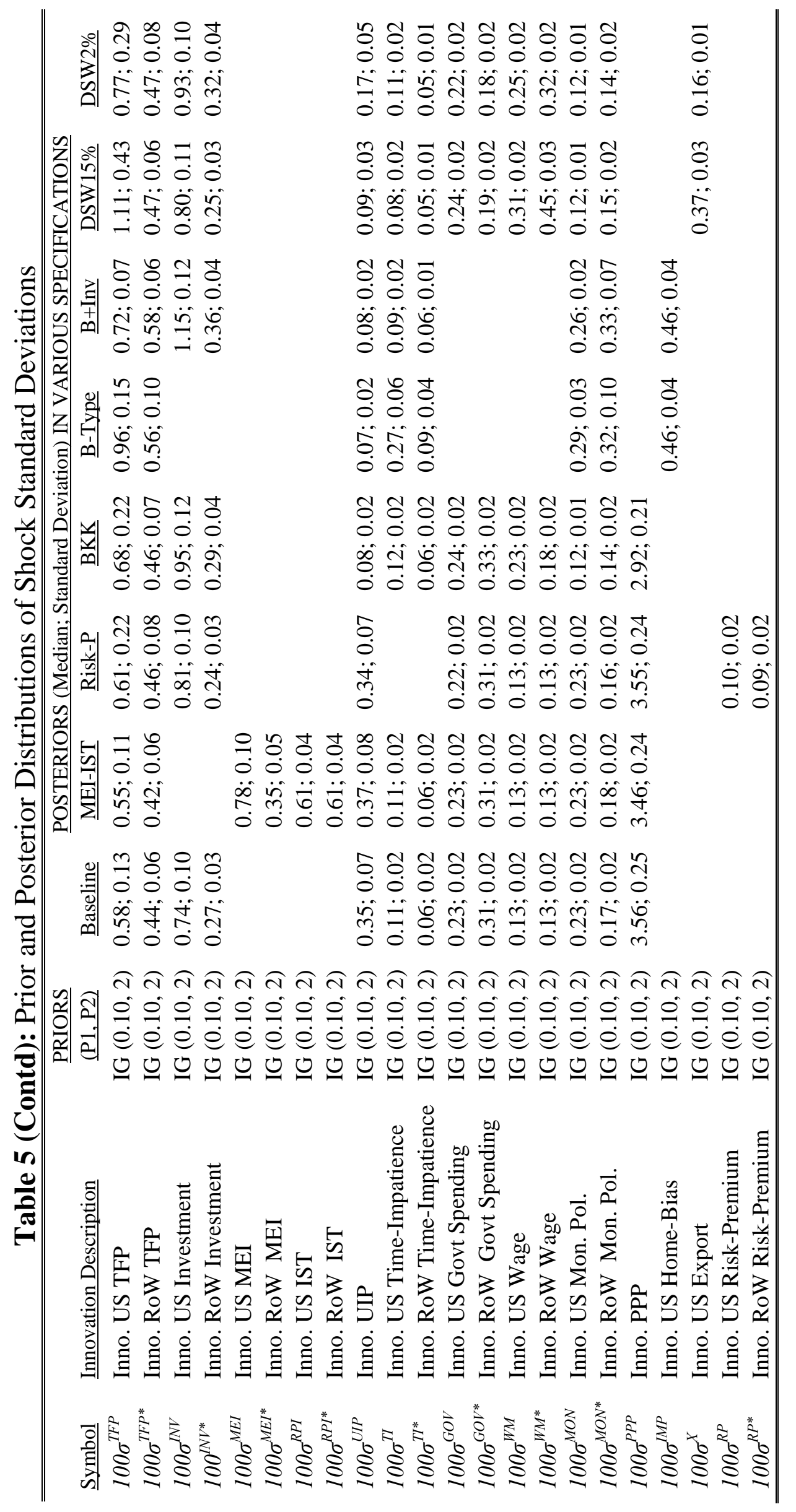

